\title{
PRECOLUMBIAN RAW-MATERIAL EXPLOITATION IN SOUTHERN PERU-STRUCTURES AND PERSPECTIVES*
}

\author{
EXPLOTACIÓN DE MATERIAS PRIMAS PRECOLOMBINAS \\ EN EL SUR DE PERÚ-ESTRUCTURAS Y PERSPECTIVAS
}

\author{
Thomas Stöllner ${ }^{1}$, Markus Reindel ${ }^{2}$, Guntram Gassman ${ }^{3}$, \\ Benedikt Gräfingholt ${ }^{4}$ and Johny Isla Cuadrado 5
}

\begin{abstract}
The article deals with the exploitation of raw materials during pre-colonial times in Southern Peru especially pre-Columbian mining and quarrying activities in the valleys of Palpa and Nasca. Between 2006 and 2009 the Peruvian-German Palpa-project has discovered several places related to the extraction and the processing of lithic material, ores and minerals. All places detected so far are locations with traces of small scale mining. The available evidence demonstrates that production of raw materials has been carried out since the earliest periods of pre-Columbian occupation of the region. Obsidian was transported to the coast since the archaic period and can be considered as evidence of the mobility of the earliest settlers. Gold processing is present in the region at least since the Early Paracas period: Its regional usage increased during the late Paracas and the Nasca-period: many small scale mining operations could be found that provide insight into the organisational level. In nearly all cases the Paracas and Nascapopulations have used and processed the rich mineral occurrences nearby the settlement areas. There are arguments either to relate metal objects with the coastal Nasca-Ocoña belt or with the large central Andean silver bearing deposits around the Lake Titicaca.

Key words: Pre-colonial mining, technology, provenance studies.
\end{abstract}

En este artículo se describe la explotación de materias primas durante los periodos precoloniales en el sur del Perú. El enfoque principal está en las investigaciones sobre minería en los valles de Palpa y Nasca entre 2006 y 2009 (cooperación peruanoalemana en los valles de Palpa). Todos los sitios descubiertos hasta el momento presentan evidencias de minería a escala pequeña. La evidencia disponible demuestra que la extracción de materias primas se practicaba desde los periodos más tempranos de la ocupación de la región. Obsidiana fue transportada hacia la costa desde el periodo Arcaico y puede ser considerado, por lo tanto, como evidencia de la movilidad de las culturas tempranas. La minería está presente en la región por lo menos desde el periodo Paracas Temprano. Su uso regional se incrementó desde la fase tardía del periodo Paracas y desde el periodo Nasca. Se encontraron muchos sitios de actividad minera a pequeña escala que proporcionan datos sobre el nivel de organización de los trabajos mineros. En casi todos los casos los ricos minerales fueron procesados dentro de asentamientos grandes. Hay argumentos para relacionar los objetos metalles con la formación Nasca-Ocoña o bien con los ricos depósitos de plata alrededor del lago Titicaca.

Palabras claves: minería precolonial, tecnología, estudios de procedencia.

Since 1997 the German Archaeological Institute has engaged in archaeological investigations in the northern Nasca region, on the south coast of Peru (Reindel and Wagner 2009). In addition to the documentation and archaeological investigations of the Nasca geoglyphs, settlement patterns have been the main focus of the project. During our surveys and investigations the discovery of metal

* Artículo seleccionado del conjunto de ponencias presentadas en la Primera Reunión Internacional sobre Minería Prehispánica en América (PRIMPA), realizada en San Pedro de Atacama, Chile, diciembre 2010. Este manuscrito fue evaluado por investigadores externos y editado por Diego Salazar y Valentina Figueroa, en su calidad de editores invitados de la Revista.

1 Deutsches Bergbau-Museum Bochum, Forschungsstelle Archäologie und Materialwissenschaften, Fachbereich Montanarchäologie, Herner Straße 45, 44787 Bochum, Germany.thomas.stoellner@bergbaumuseum.de and Institut für Archäologische Wissenschaften, chair of Pre- and Protohistory, Universitätsstr. 150, 44780 Bochum, Germany. thomas.stoellner@ ruhr-uni-bochum.de

2 German Archaeological Institute, Commission for Archaeology of Non-European Cultures, Dürenstr. 35-37, 53173 Bonn, Germany, Reindel@kaak.dainst.de

3 Kastellweg 10, 72072 Tübingen, argus.gassmann@t-online.de

4 Institut für Archäologische Wissenschaften, Fach Ur- und Frühgeschichte, Universitätsstr. 150, 44780 Bochum, Germany. Benedikt.Graefingholt@ruhr-uni-bochum.de

5 Instituto Andino de Estudios Arqueológicos (INDEA), Lima, Av. Mariátegui 155, Dpt. 111, Jesús María, Lima 11, Perú. isla-nasca@amauta.rep.net.pe 
artifacts, mineral products, mines and quarries, as well as places for the processing of mining products indicated the importance of mining activities in the region. Still today, gold and copper mining is a major income source in the region, which is characterized by a geological belt of rich ore and mineral deposits (Schulz 2007).

In 2006 the Palpa-project began to cooperate closely with the German Mining Museum in Bochum that specializes in the investigation of mining activities of ancient cultures worldwide (e.g. Stöllner et al. 2003, 2008). During the first phase of initial studies we obtained a first overview of precolonial mining in Southern Peru (Stöllner 2009, 2011; Stöllner and Reindel 2007). The research area comprises the valleys of Palpa, in the northern Nasca region (Figure 1). In the first phase of the Nasca-Palpa project we concentrated on the coastal region at the foothills of the Andes. Beginning in 2008 we expanded our research area to the highlands and to the Pacific shore and defined a transect line through the different ecological zones between the desert coast and the highest peaks of the western slope of Andean highlands, which we call the "Andean Transect". Therefore it was self-evident to expand our interest also to the exchange of raw materials and technical innovations between the coastal areas and the highlands.

Along this Andean Transect we have registered about 1600 archaeological sites so far, most of them settlements. These sites span duration from the first occupation of the region in the paleoindian period until the end of the pre-Columbian period (Figure 2) (recently Unkel et al. 2012).

The aim of our project is to reconstruct settlement shifts as influenced by climatic variations in this representative region of the Andes. Archaeologically we focus on the changing patterns of movement of people and goods over time. Following the model of verticality, in this context the movement and exchange of mining products is of crucial importance. In this paper we will present the preliminary results of our surveys and investigations concerning mining activities. From the beginning of our research it was clear that each of the settlement areas within the Transect had its special raw material basis including copper and gold ores and special lithic material at the coast and obsidian from the Altiplano.
We know from our geoarchaeological studies that over time, settlements shifted considerably between the Highlands and the coast due to changes in climate and landscape conditions (Figure 3) (Eitel et al. 2005; Eitel and Mächtle 2009). Our settlement distribution maps shows that the coastal region experienced an important increase in population from the highlands in the Paracas period, a time which was characterized by generally more humid conditions than today. In the early and middle Nasca period, settlements concentrated on the coast. It was only in the late Nasca period, when climatic conditions became extremely dry, that this tendency reversed and the settlement movements shifted towards the middle reaches of the valleys and to the highlands. In the Middle Horizon the coastal region was nearly completely abandoned and people moved to the highlands. Only in the Late Intermediate Period, when climatic conditions became more humid again and therefore favourable for settlement and agriculture, did people return from the highlands in order to establish new settlements on the coast and on the western slopes of the Andes. This sequence shows that constant movement between the highlands and the coast took place over the centuries/millennia and that presumably people had constant contact and moved or exchanged goods between these regions to obtain the raw materials for their economic activities.

\section{Geology and Raw-Material Use of the Palpa and Nasca Region: State of the Art}

Considering the metal resources in southern Peru, the main formations with gold or copper-bearing mineralisation are the "Batolito de la Costa" and the "Complejo Bella Union". The metal deposits consist of epithermal or hydrothermal veins oriented parallel to the western cordillera in most cases. Host rocks are either Jurassic or Cretaceous volcanic or sedimentary-volcanic rocks. The copper deposits regularly also contain a smaller amount of noble metals, lead and zinc. Also native gold-silver fine disseminated in hydrothermal quartz veins are found. The whole metal ore district is designated as the Nasca-Ocoña belt (Petersen 1979, 1989) (Figure 4).

Some of metal bearing veins appear near the surface and constitute a rich zone for mining today and in pre-Columbian times. Some of the ores are 


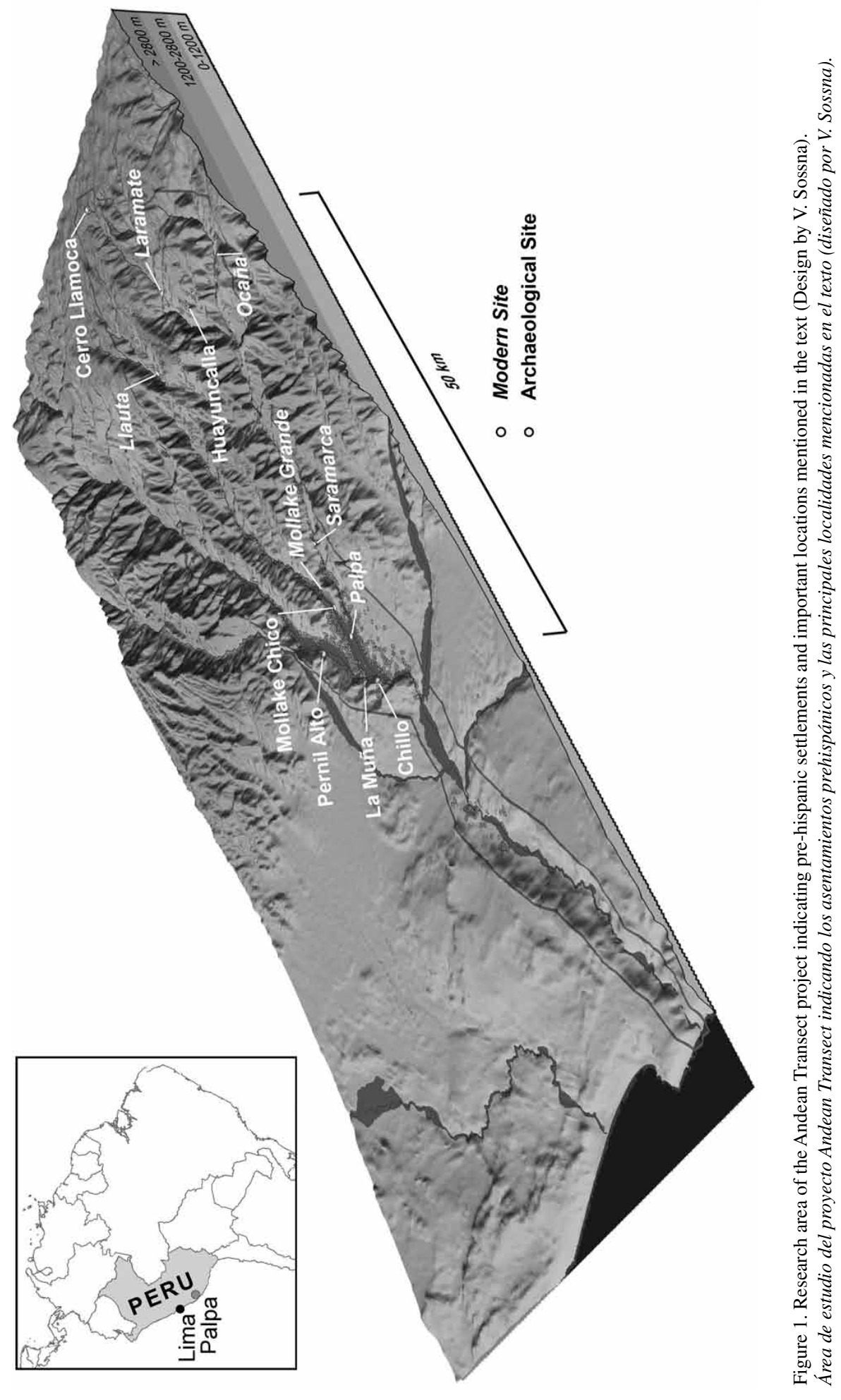




\begin{tabular}{|c|c|c|c|c|c|c|c|}
\hline YEARS & & PERIODS & CULTURES & PHASES & CERAMIC STYLE & SITES & RAW MATERIALS \\
\hline $1535 \mathrm{AD}$ & & LATE HORIZON & Inca/Ica & & Inca/Ica & & \\
\hline $1180 \mathrm{AD}$ & & $\begin{array}{l}\text { TE INTERMEDIATE } \\
\text { PERIOD } \\
\end{array}$ & Ica & & Ica & $\begin{array}{l}\text { Chillo, } \\
\text { Montegrande }\end{array}$ & $\begin{array}{c}\text { copper, gold, } \\
\text { obsidian }\end{array}$ \\
\hline \multicolumn{8}{|l|}{$850 \mathrm{AD}$} \\
\hline $\begin{array}{r}790 \mathrm{AD} \\
690 \mathrm{AD}\end{array}$ & & $\begin{array}{c}\text { MIDDLE } \\
\text { HORIZON }\end{array}$ & Wari & & Chakipampa & $\begin{array}{l}\text { Huayuncalla, } \\
\text { Primavera, }\end{array}$ & $\begin{array}{c}\text { copper, gold, } \\
\text { obsidian }\end{array}$ \\
\hline $660 \mathrm{AD}$ & & & & & Loro & Montegrande & \\
\hline $\begin{array}{r}620 \mathrm{AD} \\
470 \mathrm{AD}\end{array}$ & \multirow{2}{*}{\multicolumn{2}{|c|}{$\begin{array}{c}\text { EARLY } \\
\text { INTERMEDIATE } \\
\text { PERIOD }\end{array}$}} & & Late & Nasca (6?), 7 & & \\
\hline $\begin{array}{l}410 \mathrm{AD} \\
340 \mathrm{BC}\end{array}$ & & & Nasca & Middle & Nasca 4,5 & La Muña & $\begin{array}{l}\text { gold, copper, } \\
\text { obsidian, malachite, } \\
\text { chrysocolle, turquoise }\end{array}$ \\
\hline $270 \mathrm{AD}$ & & & & Early & Nasca 2,3 & $\begin{array}{l}\text { Saramarca, } \\
\text { Mollake Grande, } \\
\text { Primavera, } \\
\text { Montegrande }\end{array}$ & $\begin{array}{l}\text { gold, copper, } \\
\text { obsidian }\end{array}$ \\
\hline $130 \mathrm{BC}$ & \multicolumn{2}{|r|}{ TRANSITION } & Initial Nasca & & $\begin{array}{c}\text { Nasca } 1 \\
\text { Ocucaje } 10\end{array}$ & & $\begin{array}{c}\text { gold, } \\
\text { obsidian }\end{array}$ \\
\hline $3330 \mathrm{BC}$ & \multirow{6}{*}{ 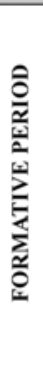 } & & & Late & Ocucaje 8, 9 & $\begin{array}{l}\text { Saramarca, } \\
\text { Mollake Grande, }\end{array}$ & $\begin{array}{c}\text { gold, } \\
\text { obsidian }\end{array}$ \\
\hline $440 \mathrm{BC}$ & & & & Midll & Onanie 57 & Montegrande & \\
\hline & & & Paracas & Midale & Ocucaje $5, \mathbf{0}, 7$ & & obsidian \\
\hline $560 \mathrm{BC}$ & & $\begin{array}{c}\text { EARLY } \\
\text { HORIZON }\end{array}$ & & Early & Ocucaje 3,4 & & $\begin{array}{l}\text { gold, } \\
\text { obsidian }\end{array}$ \\
\hline $800 \mathrm{BC}$ & & & & & & & \\
\hline $900 \mathrm{BC}$ & & $\begin{array}{l}\text { INITIAL } \\
\text { PERIOD }\end{array}$ & & & $\begin{array}{l}\text { Puerto Nuevo } \\
\text { Disco Verde } \\
\text { Hacha }\end{array}$ & Pernil Alto & obsidian, silex \\
\hline \multicolumn{3}{|l|}{$1500 \mathrm{BC}$} & & & & & \\
\hline \multirow[t]{2}{*}{$2895 \mathrm{BC}$} & \multirow{2}{*}{\multicolumn{2}{|c|}{ ARCHAIC }} & & & \multirow{3}{*}{ no ceramics } & & \\
\hline & & & & & & Pernil Alto & obsidian, silex \\
\hline $8000 \mathrm{BC}$ & & & & & & Cerro Llamoca & obsidian, silex \\
\hline
\end{tabular}

Figure 2. Precolumbian chronology of South Peru (Design by M. Reindel, Bonn).

Cronología precolombina del sur de Perú (diseñado por M. Reindel).

extremely rich in gold and copper, sometimes iron oxide is present.

In contrast to the northern coast of Peru (see e.g. the article of Shimada and Craig in this volume) and also to the central Andean Altiplano, southern Peru never was a focal area of metallurgical inventions or innovations. Archaeological investigations concerning mining in southern Peru were intensified in recent years by American and German research groups, which focused on the use of pigments and metal ores by the ancient inhabitants of the Nasca-Palpa region (Eerkens et al.2009; Schlosser et al. 2009; Stöllner 2009; Stöllner and Reindel 2007; Vaughn et al. 2007). Root and Lechtman started to review this situation and asserted that extensive use of copper objects can be observed mainly in the late periods of the south coast of Peru (Root 1949; Lechtman 1976). This more or less coincides with northern Chile assisted by investigations (e.g. Núñez Atencio 1999) conducted in the copper mining districts around Chuquicamata and El Abra; these results also made apparent the considerable late use of copper in these regions basically within the later Formative (Figueroa et al. 2010; González y Westfall 2005, 2008; Salazar 2008).

In the south coast of Peru gold was the first metal that came into use during the Paracas culture (Tello 1959; Tello and Mejía Xesspe 1979; Uhle 1913). And also during the Nasca period the metallurgy principally remained on a basic level of cold working 


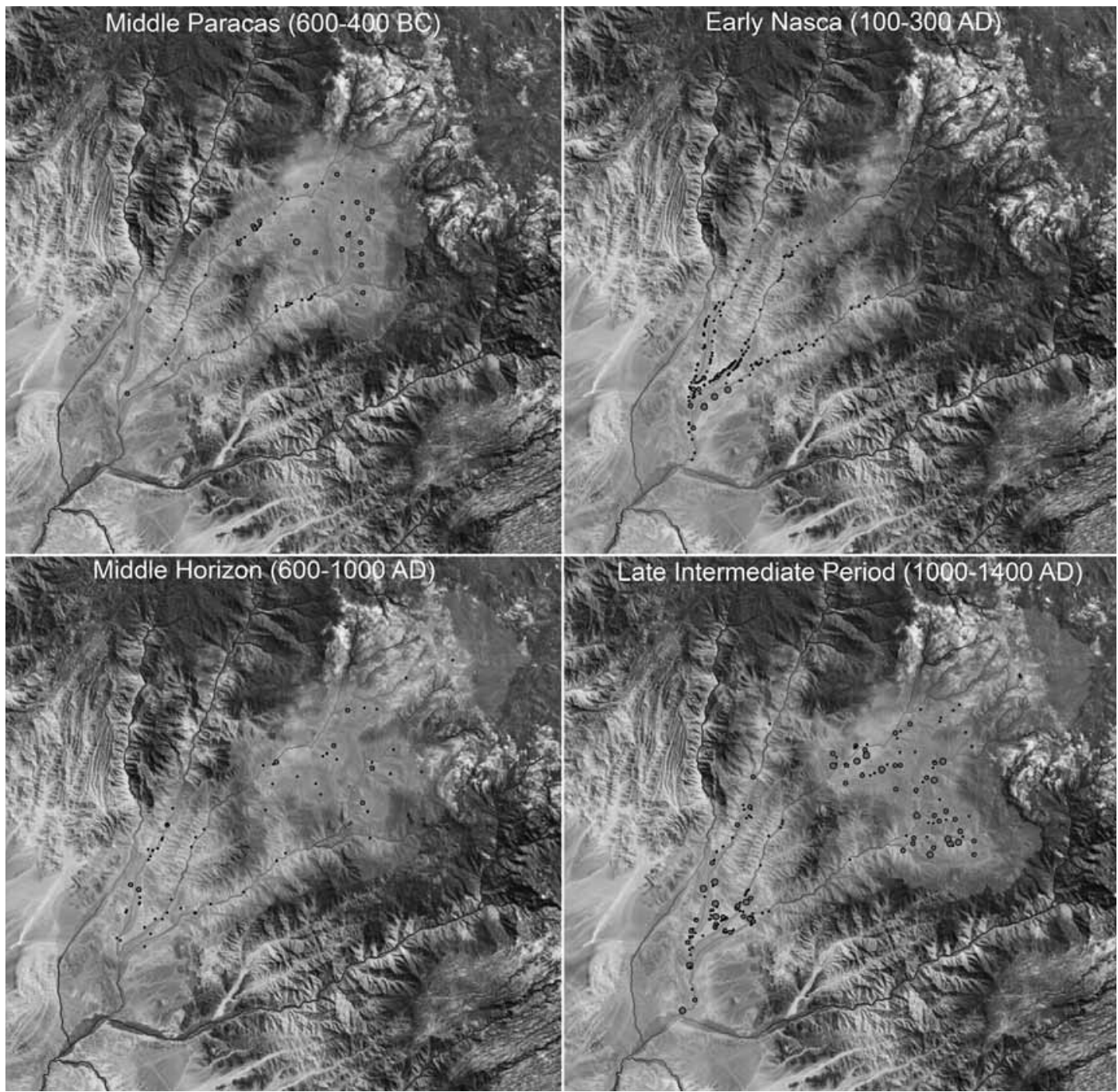

Figure 3. Settlement patterns within the research area in different periods (Design by V. Sossna).

Patrón de asentamiento en el área de estudio durante diferentes periodos (diseñado por V. Sossna).

of gold as well as the first simple copper working techniques (Schlosser et al. 2009). Consequently W. Root concluded that the Paracas and Nasca had developed a comparatively simple and low level gold-metallurgy perhaps under influence of Northern coastal cultures such as Chavín (Lothrop 1937; Lothrop 1951; Root 1949).

Natural gold alloys are dominant in regional metal assemblages. The metallurgy especially of the Nasca period remains enigmatic up to now: While some slag-sites and remnants of copper metallurgy is known (e.g. Lechtman 1976), the smelting of complex sulphides or poly-metal copper ores is not to be expected even before the end of the Nascaculture (around AD 600)-but this certainly needs more detailed field-work for a confirmation.

A considerable increase of metallurgy is notable only from the Ica-phases onward (Late Intermediate Period). In this phase not only an increase of metal artifacts can be observed, but also the variation of metal compositions indicate external influences on the basis of an intensified trade especially with the Altiplano. But if this impression is correct, remains uncertain until more metal artifacts are investigated regarding their chemical composition and their manufacturing technique. 


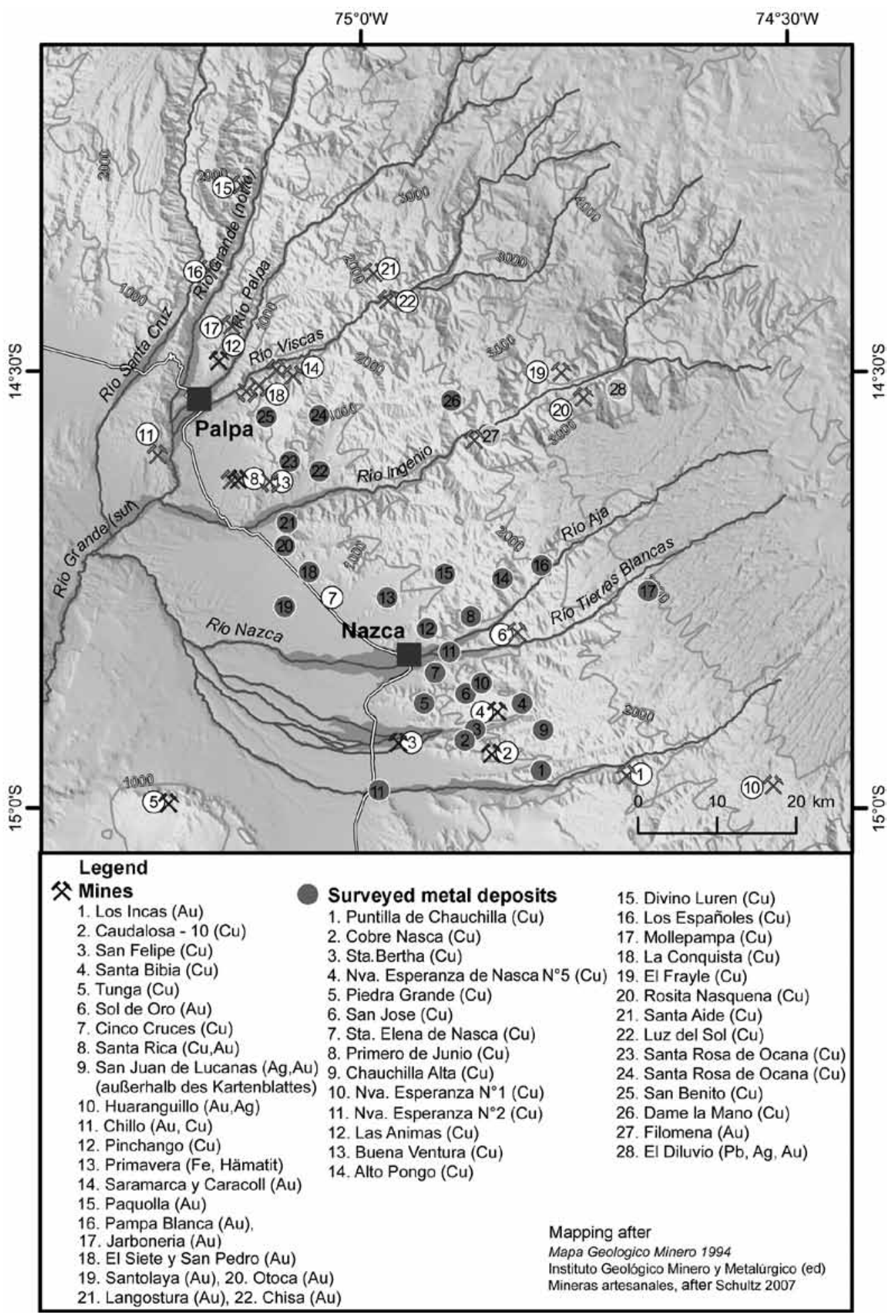

Figure 4. The copper and gold deposits in the surroundings of Palpa and Nasca and their prehistoric and recent use (after Stöllner 2009:402, Figure 23.6).

Los depósitos de cobre y oro en las inmediaciones de Palpa y Nasca y sus usos prehistóricos y actuales (según Stöllner 2009:402, Figura 23.6). 
Beside metals also other minerals stood in discussion: After studying and analysing artifacts from museums and excavations, H. Ruppert postulated in 1982 that turquoise deposits existed in southern Peru (Ruppert 1982, 1983; Petersen 1970). So far no major deposits have been located. Many sources of turquoise, however, have been located in northern Chile and their pre-colonial exploitation recently has been investigated (González and Westfall 2005, 2008).

Finally also Obsidian needs careful discussion: In the south of Peru and the north of Chile and Bolivia many obsidian sources have been investigated and geochemically characterized. Of these, however, there were major sources that have played an important role in the long-distance trade networks such as Quispisisa and Jampatilla in the highlands of Ayacucho (Burger and Asaro 1979; Burger et al. 2000; Tripcevich y Contreras 2011).

Stone, mineral and metal artifacts through the pre-Columbian history of Palpa and Nasca

One of the most common products that were brought from the highlands to the coast from the earliest to the latest periods was obsidian. We found obsidian flakes and artifacts for example in all layers of a test excavation in a rock shelter at an altitude of $4300 \mathrm{~m}$, near the Cerro Llamoca, where the lower levels dated to $8,000 \mathrm{BC}$. In the oldest levels we found the obsidian artifacts mixed with other lithic materials like silex and other fine crystalline minerals (Figure 5). On the coast we recovered obsidian projectile points in the archaic layers of Pernil Alto, which date to the 4th millennium BC (Figure 6) (Isla 2009; Reindel

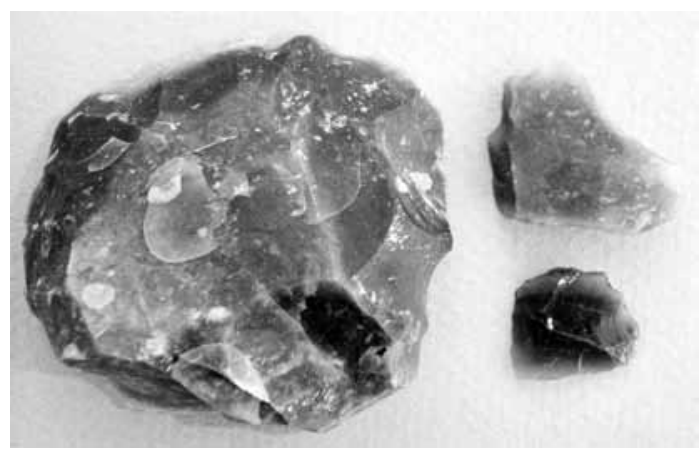

Figure 5. Artifacts recovered in the lowest layers of a test excavation at the Llamoca rock shelter $\left(8^{\text {th }}\right.$ millenium BC).

Artefactos recolectados en los niveles más profundos de la excavación del alero Llamoca (Octavo Milenio a.C.).
2009, 2010; Reindel and Isla 2006). Pernil Alto is a site which represents the stage of initial sedentism on the south coast of Peru. The settlement is composed of round or oval pit houses, similar to the ones excavated at Paloma and Chilca (Benfer 1999; Engel 1966, 1980, 1988).

The earliest use of metals in Palpa, in this case a gold ring, dates to the early Paracas period (Figure 7). This gold ring was found in a burial chamber associated with typical Early Paracas ceramics with some influence of the Cupisnique culture (Isla and Reindel 2006a; Reindel and Isla 2006). This fits to the before mentioned influence of the Chavín horizon in fairly simple gold working and the spread of the famous Chavín style (Lothrop 1951).

Gold objects from the Nasca period are known from the elite burials of La Muña (Fig. 8) (Reindel and Isla 2001; Isla and Reindel 2006b). The use of gold objects in the Nasca period was more common, although it never reached the level of the cultures of the north coast of Peru, like the Moche or Sicán. The finds of La Muña show also that in the Nasca period copper came into use, as evidenced by the copper beads recovered from the tombs of La Muña. Several secondary copper minerals like malachite, chrysocolla and turquoise were also common. These semiprecious minerals were used also as pigments during the Nasca period. Another pigment which is often found in burials is hematite.

In the Middle Horizon the use and the number of copper objects rose significantly. In 2010 we excavated several undisturbed burials at the highland Huari site Huayuncalla. Huayuncalla is located at an altitude of 3,200 $\mathrm{m}$ at the upper reaches of the Viscas river (Figure 1). Two rectangular burial chambers were excavated that were enclosed by circular walls. In each burial chamber we found secondary burials with 20 individuals, accompanied by Huari ceramics and metal objects. The copper objects included tupus, different adornments, spear throwers and other tools (Figure 9). At the bottom of each burial chamber were found large discs of gold foil. The sheer amount of copper objects shows that a real boom of the use of copper occurred during the Middle Horizon.

This picture continues into the Late Intermediate Period. Although our excavations of sites of this period were limited, the presence of copper and gold objects even on the surface of sites of the Late Intermediate Period is obvious. 

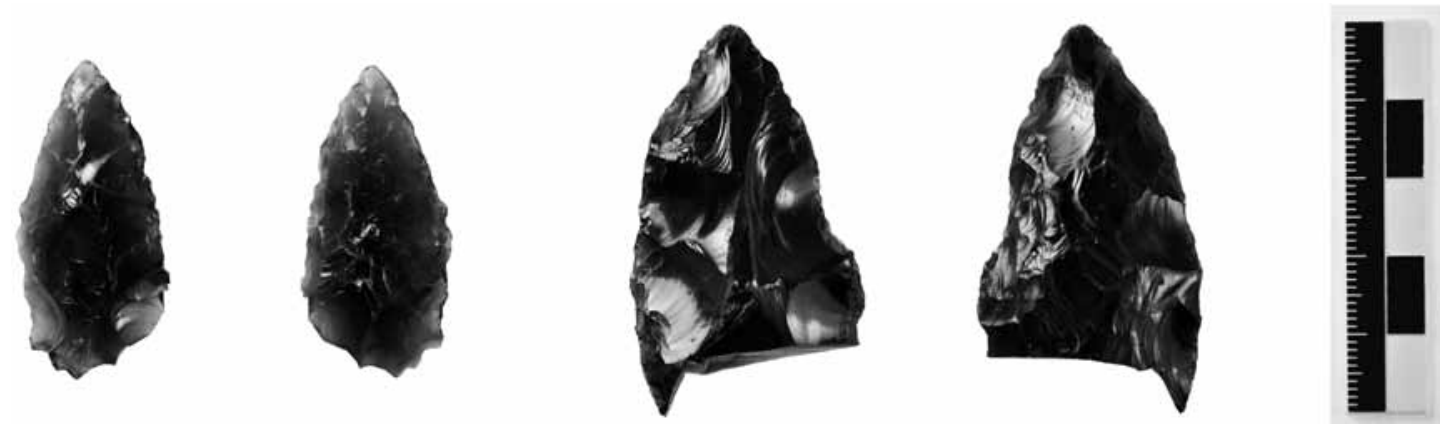

Figure 6. Obsidian projectile points recovered at the excavation of the archaic settlement Pernil Alto ( $4^{\text {th }}$ millenium BC) (Foto by B. Gräfingholt, RUB).

Puntas de proyectil de obsidiana procedentes de la excavación del asentamiento arcaico Pernil Alto (Cuarto Milenio a.C.) (Foto de B. Gräfingholt, RUB).

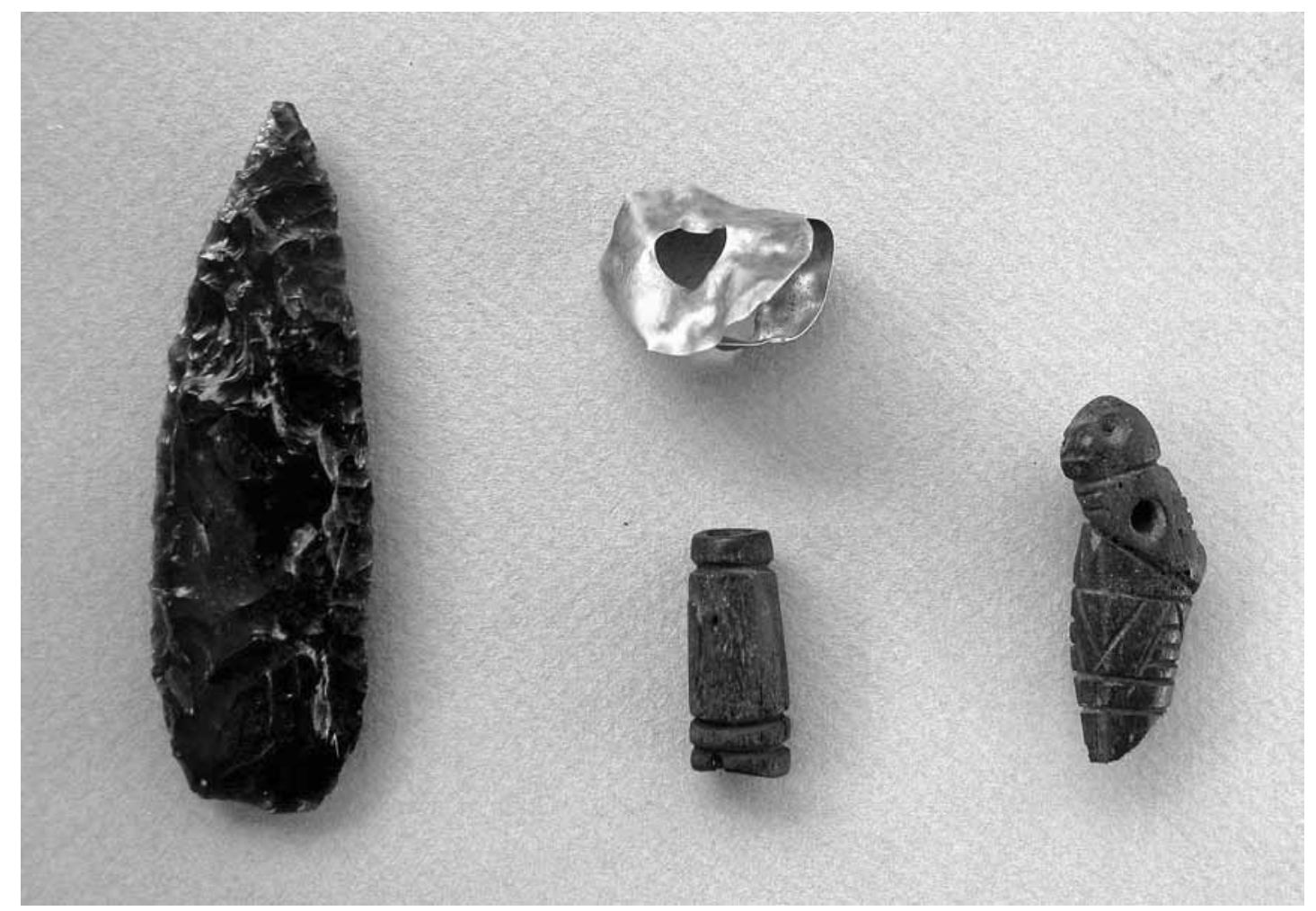

Figure 7. Obsidian projectile point, gold ring and stone beads recovered at the excavation of an Early Paracas tomb at Mollake Chico ( $8^{\text {th }}$ century BC) (Foto by J. Isla).

Punta de proyectil de obsidiana, anillo de oro y cuentas de collar líticas halladas en la excavación de una tumba Paracas Temprano en Mollake Chico (Siglo 8 a.C.) (Foto de J. Isla). 

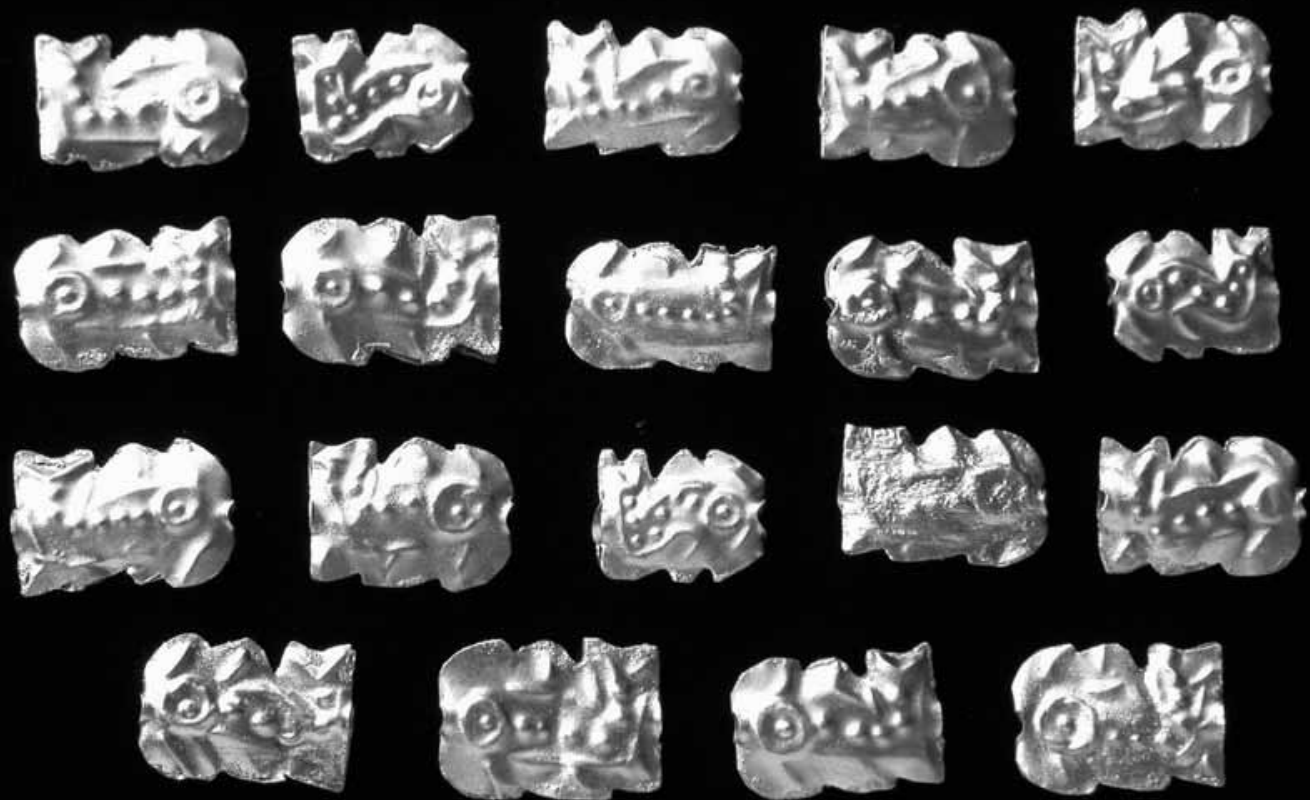

Figure 8. Gold beads representing fishes recovered at the excavation of a Middle Nasca tomb at La Muña (400 AD) (Foto: DAI, M. Reindel)

Cuentas de oro representando peces encontradas en la excavación de una tumba Nasca Medio en La Muña (400 d.C.) (Foto: DAI, M. Reindel).

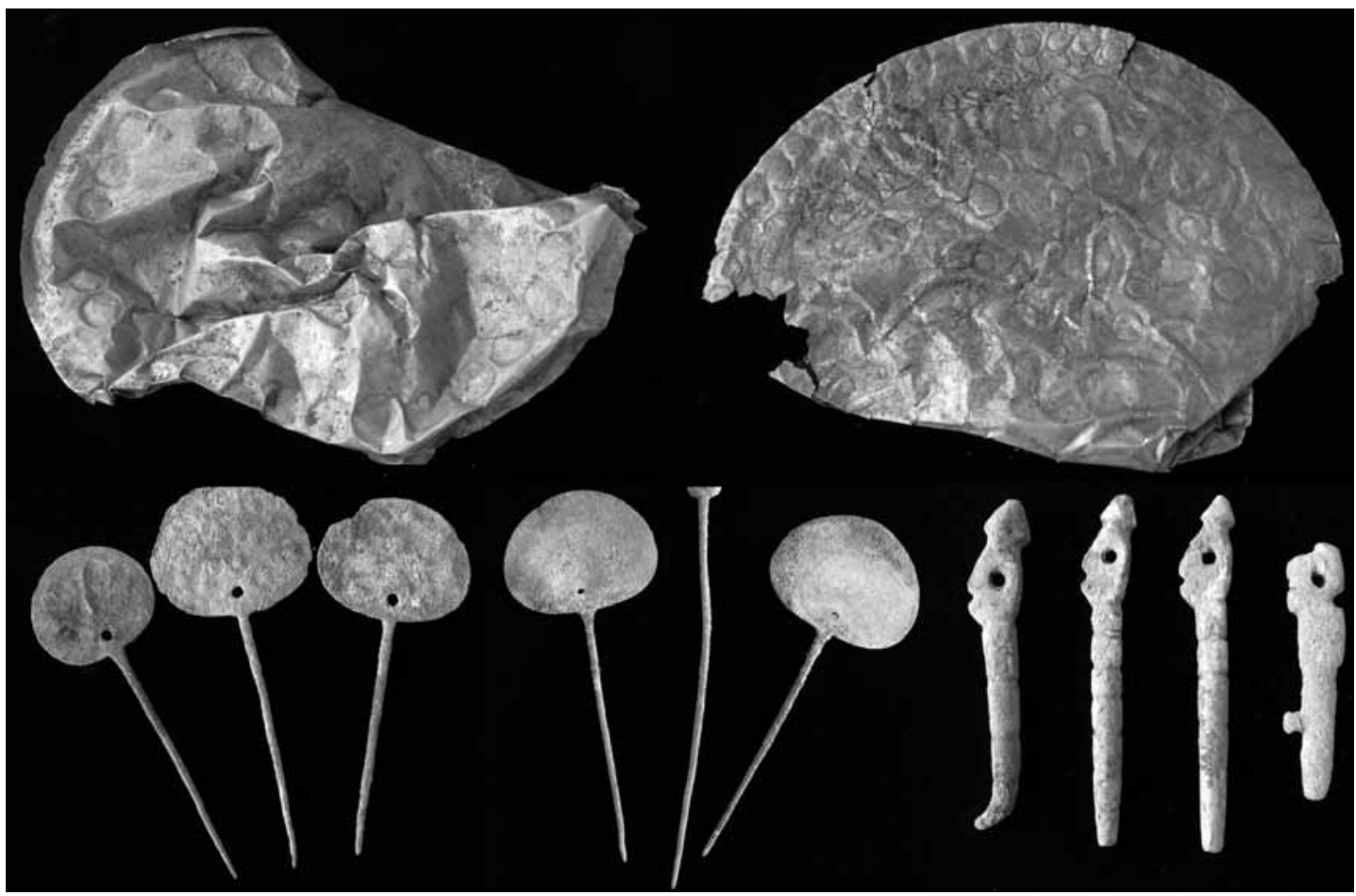

Figure 9. Gold and copper objects recovered at the excavation of Huari tombs at Huayuncalla (700 AD) (Foto by DAI, M. Reindel). Objetos de oro y cobre encontrados en la excavación de tumbas Huari en Huayuncalla (700 d.C.) (Foto de DAI, M. Reindel). 


\section{Mining Archaeology in Palpa and Nasca: Survey in 2006 and 2009}

In order to gain a better understanding of the raw material acquisition patterns of the south Peruvian Pre-colonial cultures the German Mining Museum and the German Archaeological Institute started a series of surveys in the surrounding of the Palpa region (Figure 10): In 2006 we undertook an evaluation of presumed mining and metallurgical sites in the Rio Grande, the Rio Viscas and the Rio Palpa Valley (Stöllner 2009; Stöllner and Reindel 2007). First results did convince us to follow a more systematic approach alongside the Nasca-Ocoña formation. In 2009 we carried out an extensive Survey in different valleys (quebradas) in the Nasca-Palpa region. We assumed that the mineral deposits were opened up at the mountainous flanks of the "quebradas". The team could roughly locate them by motorized surveys and by oral communications with many of the local miners (mineros artesanales) that currently are working these deposits mainly in search for gold. In suspicious areas we intensified the work through a detailed sampling, GPS-mapping, descriptions and photo-documentation. Additionally to some stratigraphical observations and the autopsies made on rock surfaces (the extraction method) and on ore-bodies the dating of the ancient mines is so far only based on surface findings of pottery sherds and the association of quarries and mines with pre-colonial settlement patterns. The mineralogical analyses and characterisation by polished sections ore-dressing and geochemical analyses by Neutron Activation Analysis (NAA) and by MC-ICP-MS (Multicollector-inductively coupled plasma mass spectrometry) were made in Bochum, Mannheim as well as at the University of Frankfurt.

\section{Mining Archaeology: First Results}

Mines and quarries were not easy to identify because in most cases, mining activities in colonial and in modern times had altered the evidence of preColumbian activities. In the case of chert quarries in the highlands, however, the traces of the extraction of material in archaic times were clear. The quarry shown in Figure 11 is close to the rock shelter at Cerro Llamoca mentioned before, where artifacts of the same material were recovered in excavations of layers that dated back to the $8^{\text {th }}$ millennium BC.
The waste dump in front of the quarry was clearly visible, where crudely worked preforms and typical artifacts like unifacial artifacts were found.

During our survey we visited the obsidian source of Jichja Parco, which is located on the way to Huanca Sancos, near the upper reaches of the Rio Grande (Figure 12). Large amounts of obsidian debris lie inside deep pits, from where the obsidian was extracted from deposits that were close to the surface. The deposits are located close to an ancient pathway that connected this site with the Palpa region. Recently this obsidian source has been identified as the place where probably most of the artifacts come from which previously had been assigned to a site called Quispisisa (Burger and Glascock 2000; Tripcevich and Conteras 2011).

Our initial survey comprised the whole Nasca area, with visits to the sites previously described by J. Eerkens, K. Vaughn and M. Linares Grados (Eerkens et al. 2009). Our field procedure was very similar to the one described by Eerkens and colleagues. After this general survey of the Nasca region we concentrated on the valleys of Palpa (Figure 10). With the background of our excavation finds, our interests were focussed on mines and quarries. Our main focus was laid on gold and copper ores. Regarding the minerals that were used for ornaments and for pigments, we concentrated on malachite, turquoise and other copper sulfates, hematite and ochre. Many of the places with mining activities were identified by locations where ores and minerals were processed. At these sites we documented mining tools and cultural finds.

South of the Nasca valley further results were gained obtained at the Las Trances valley where settlements and grave-yards of different periods are known (e.g. Chauchilla) (Figure 13). Mineral deposits are exposed on the banks of the fertile valley. The American expedition (Eerkens et al. 2009:744-745) already has mentioned smelting sites at the site of Media Luna located at the valley exit. Further autopsy however made clear that the charcoal heaps scattering in the plans in front of the hillock of Media Luna may be related to colonial charcoal burning but not to smelting from the $16^{\text {th }}$ and $17^{\text {th }}$ century: some of the very old dates published from Eerkens et al. (2009:744, Table 2) may belong to charcoal burning of fossilized wood found in the sediment layers of the valley. More interesting were several small scale mining sites that lined especially at the northern flanks of the 
valley. The location near various settlements of the late Middle Horizon and the Late Intermediate period suggests a prehispanic use of these sites. Most of them can be described as polymetallic copper-deposits and occurrences. On some sites the surface near exploitation are accompanied by small tailings and platforms delivering diagnostic pottery sherds (Pc007; Pc014: Figure 13). Most likely these platforms have served as ore-beneficiation sites while settlement areas were situated nearby the fertile grounds of the valley. Similar traces were reported for the northern tributaries of the Nasca

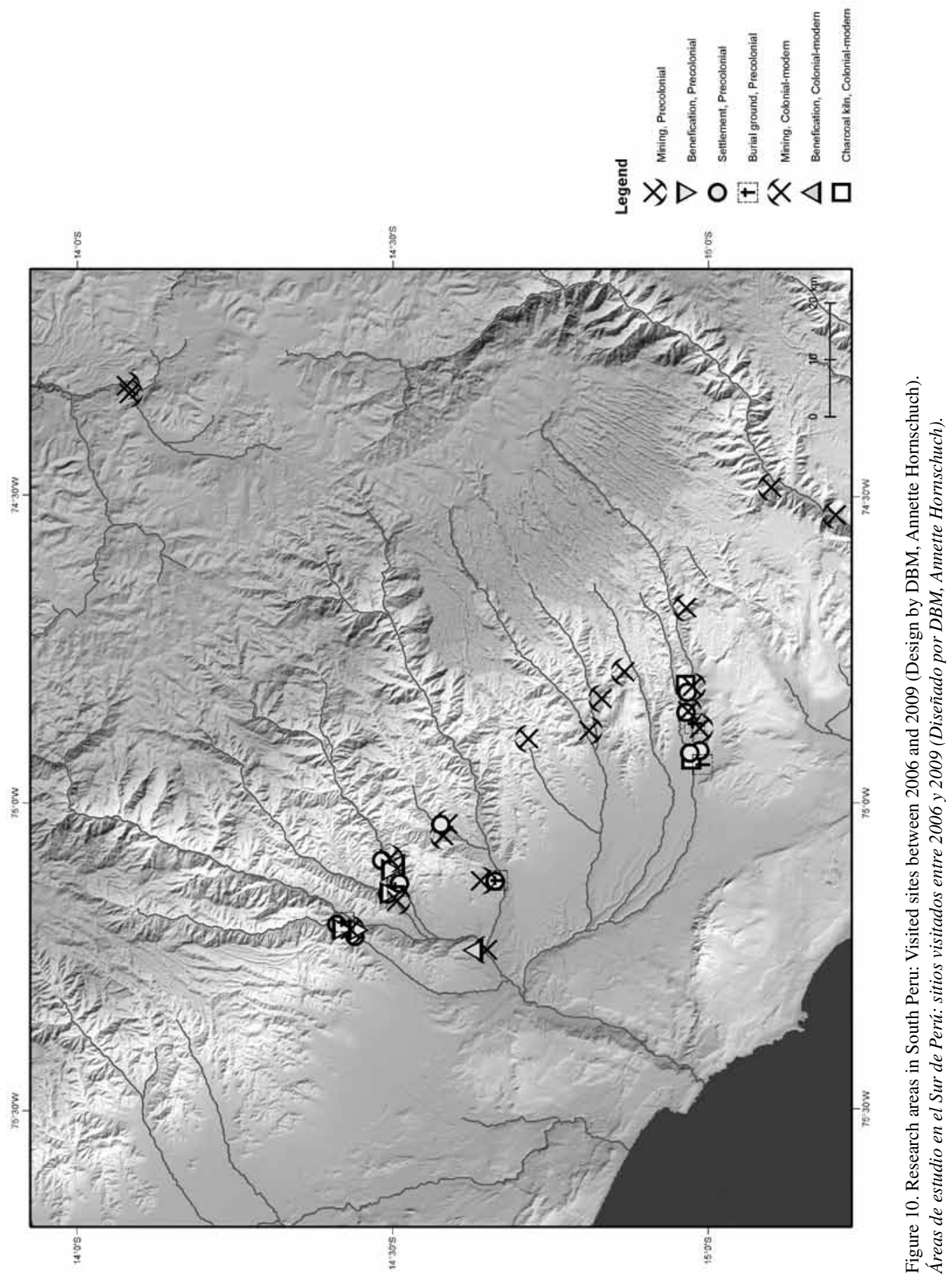




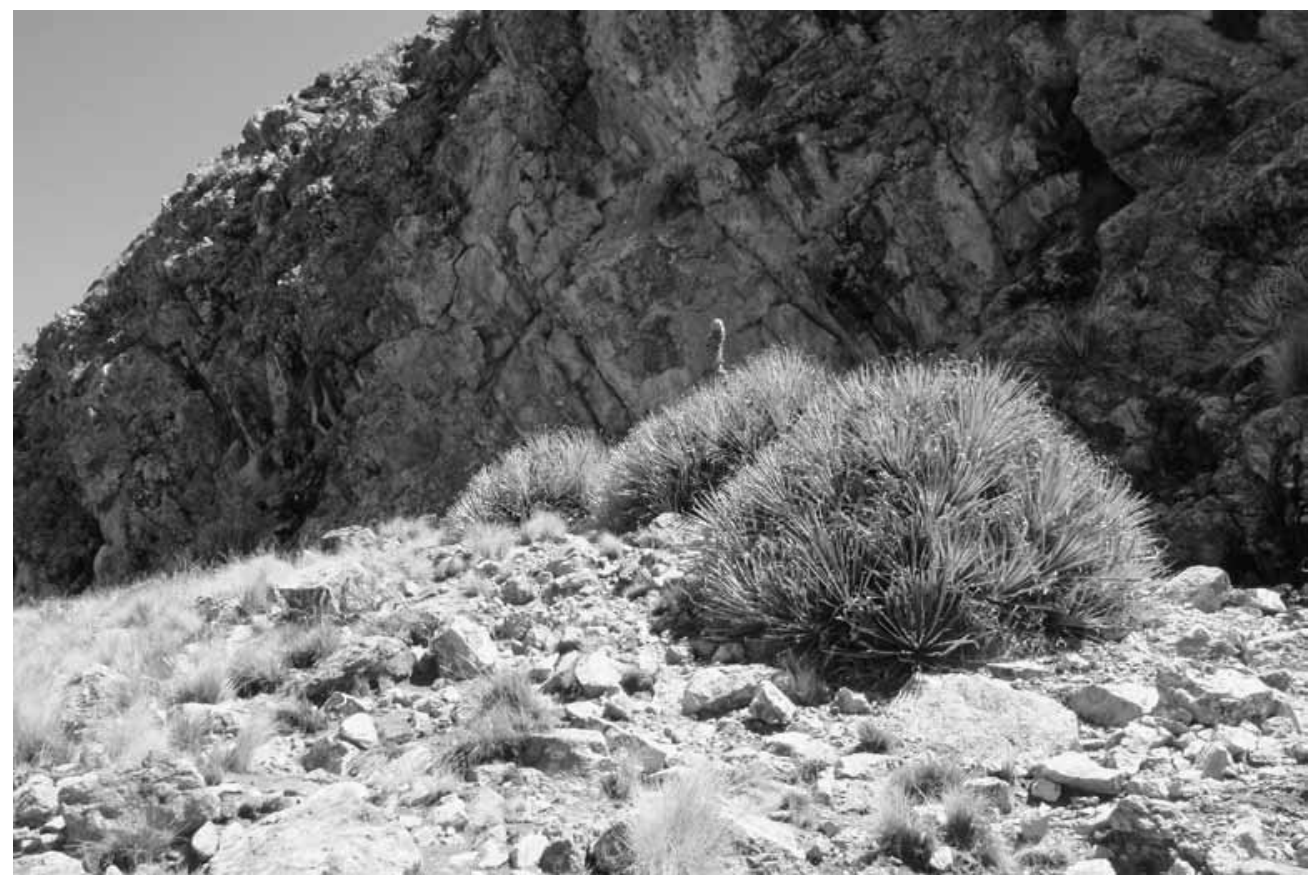

Figure 11. Chert quarry with refuse dump at the foot of Cerro Llamoca (4,200 masl) (Foto by DAI, M. Reindel). Cantera de Chert con áreas de desechos a los pies del Cerro Llamoca (4.200 msm) (Foto de DAI, M. Reindel).

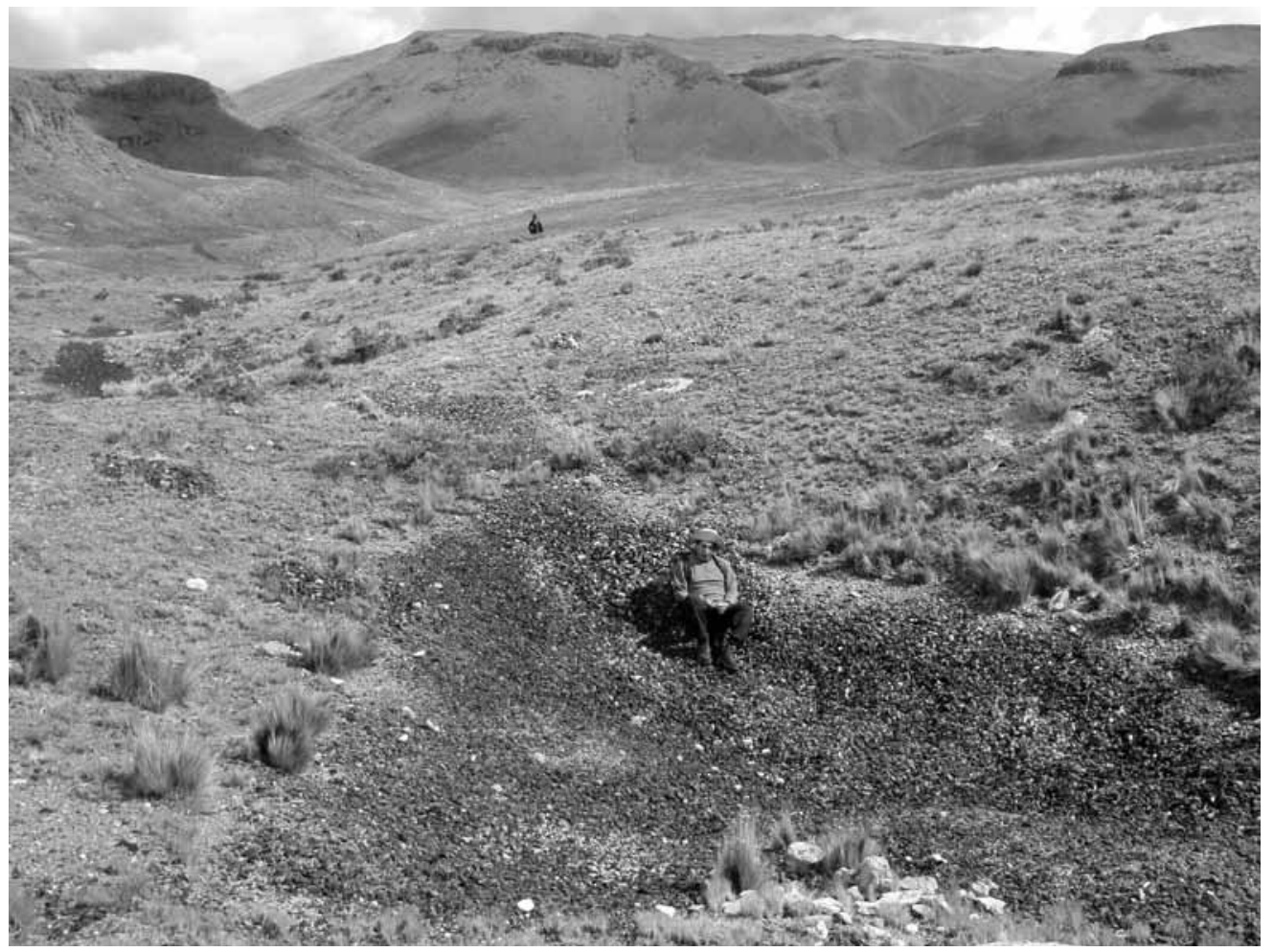

Figure 12. Peru, Cerro Jihja Parco: Precolonial obsidian mine filled by dumps of obsidian flaking debris (Foto by DBM, B. Gräfingholt). Perú, Cerro Jihja Parco: mina prehispánica de obsidiana llena de desechos de talla de obsidiana (Foto de DBM, B. Gräfingholt). 
river valley (Eerkens et al. 2009) where our team was able to locate another pre-colonial site ( $\mathrm{Pg} 002)$. The site is located at southern mountain-ridge of the Aja valley that divides this quebrada from the neighboring Tierras Blancas valley. Quartzite veins may indicate the usage of gold-bearing ores. At site $\mathrm{Pg} 002$ three small surface-near-exploitations were visible (Figure 14): One of those was a typical exploitation pocket, another one followed a quartz-vein along a natural fracture. A smaller amount of stone-tools was found at dumps beneath these extractions. Some of those certainly were belonging rather to ore-beneficiation than to the actual extraction work.

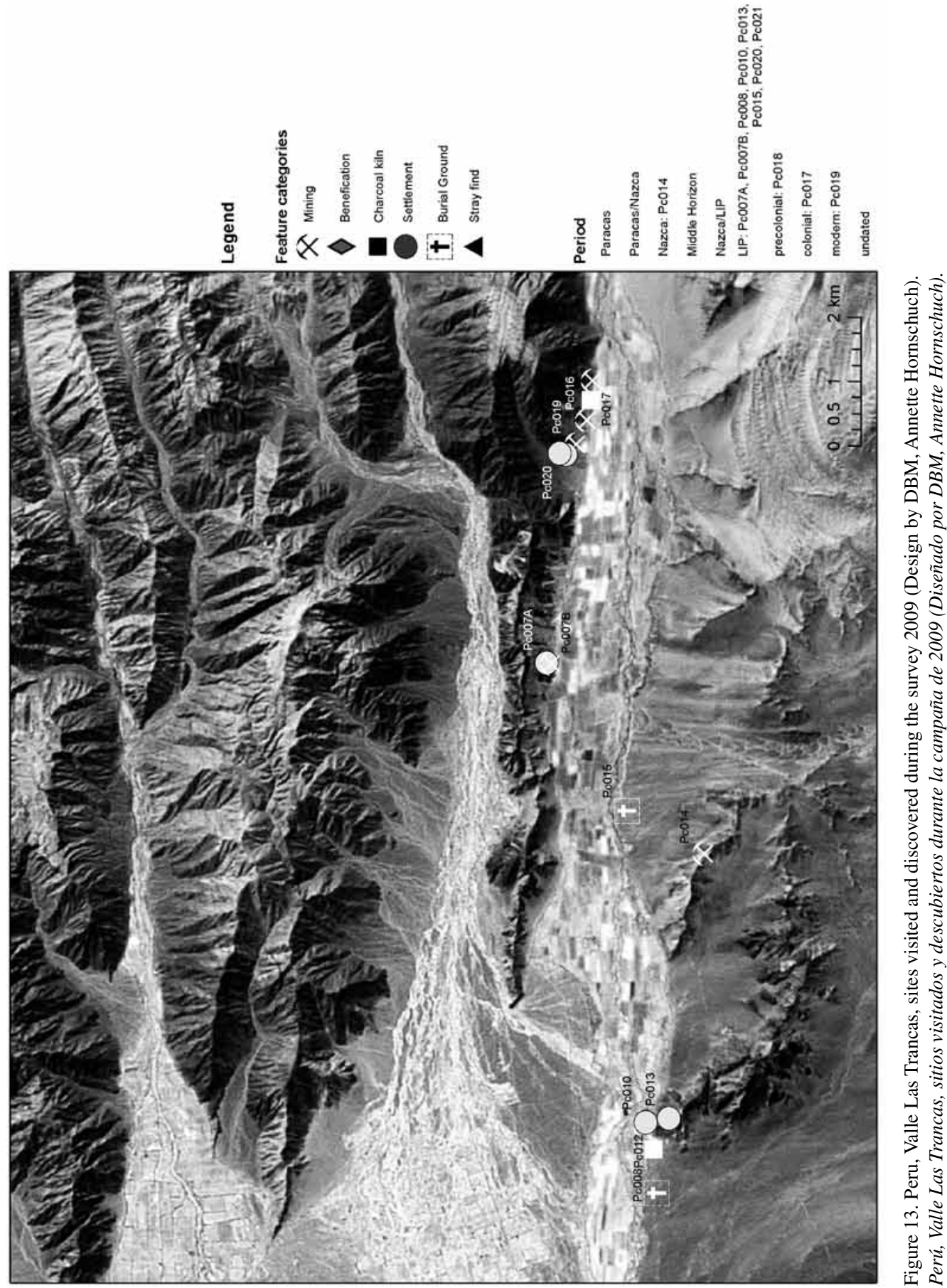




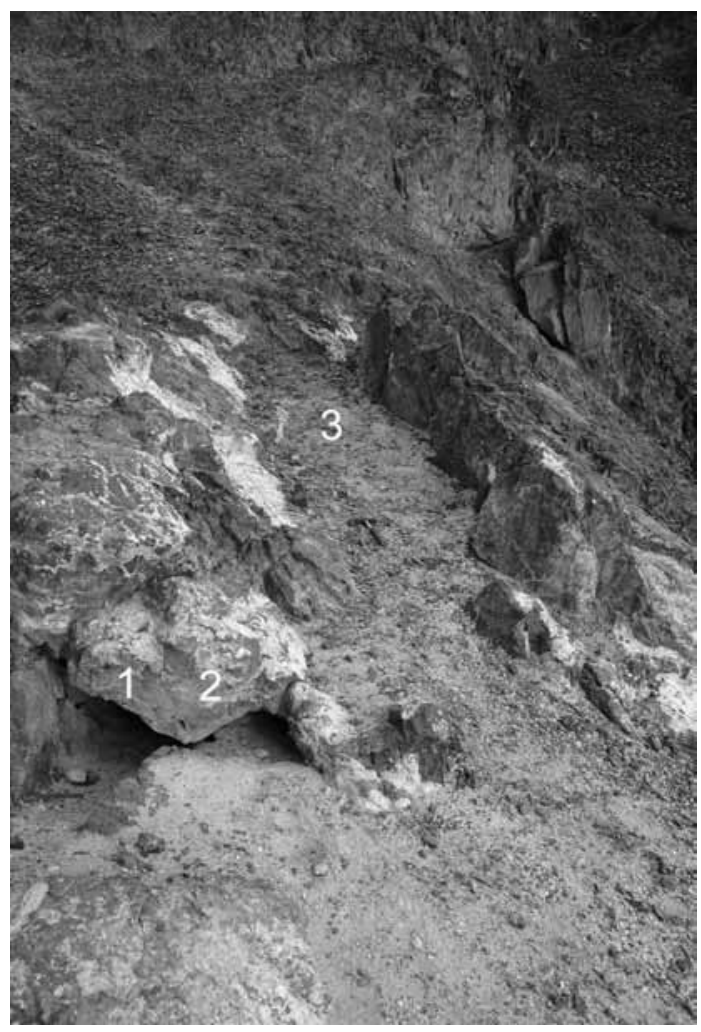

Figure 14. Peru, Aja Valley, mine 2 at site Pg002; 1,2 exploitation niches, 3 open cast winning alongside ore mineralisation (Foto by DBM, Th. Stöllner).

Perú, Valle de Aja, mina 2 en el sitio Pg002; 1, 2 nichos de explotación, 3 trincheras a cielo abierto junto a mineralización (Foto de DBM, Th. Stöllner).

In the northern valleys of the Nasca drainage interesting results were achieved nearby a settlements of the Paracas and Nasca periods near Saramarca, an area that still is in operation and famous for its gold hosting ores. At Saramarca it was difficult to find untouched mines as most of the recent mining activities have redeveloped and destroyed older traces. In some cases (e.g. site Pe 029) it was possible to distinguish surface near extractions with hammering traces from underground galleries worked with iron tools. In most cases evidence could be collected at ore-beneficiation sites that were located above the valley (Figure 15). These sites are well dated by ceramic assemblages and are contemporary to the settlements near the valley bottom (Paracas and Nasca). This certainly means that most of the mining activity was organized from these settlements. There was no need to have special mining camps, contrary to the current situation where temporal camps reflect the volatile situation of a gold rush driven by market economy and high gold prices (Kuramoto 2001; Schulz 2007). In contrast to the assumption of Eerkens et al. (2009) we could not document any evidence of pre-colonial temporal mining camps. This general impression was further clarified while we documented other sites in the Palpa valleys. In all cases permanent ancient settlements were situated nearby or even in short, easy reachable distances from the mines!

Good examples for our observation are the oreprocessing and mining sites that have been located at a mountain ridge that divides the Rio Grande and the Santa Cruz-valley. The small mining sites hosting polymetallic ores $(\mathrm{Au} / \mathrm{Cu}$ ?) are situated nearby a larger series of settlements from the Nasca and the Late Intermediate period. At the settlements we detected a stone quarry and more important ore-beneficiation consisting of crushing plates and mallets or hammers. The site of Locarí is another good example for extraction and the organizational pattern mentioned before.

Also at Mollake Grande, in the Palpa valley, we located many modern test pits, but also several pre-Columbian mines and places for ore processing that were modified by modern activities (Figures 16-17). The mill stones, mortars, hammer stones and waste dumps were associated mainly with Nasca and Paracas, and occasionally with Late Intermediate period surface remains. In some cases a clear stratigraphic sequence was observed: modern, coarse debris dumps are superimposing older dumps consisting of finer gravel and debris containing stone tools and pre-colonial pottery (Figure 18). It is interesting to note that most of the mining places were re-mined in younger periods. The ancient mining activities certainly belonged to the late Paracas and early Nazca-period while settlement terraces found above are much younger and delivered ceramic pottery from the LIP-period. It is not by mere chance that especially the Late Intermediate Period (LIP) is represented nearly at all mountainous heights in the surrounding of the Palpa-valley. Investigations of the settlement patterns have provided the insight that especially during that period such heights were in favor: either to prevent settling on fertile ground or to search for better defendable positions. If the close relation to mineral resources was another reason is debatable but not proven at the moment. The results of our settlement surveys however suggest that this region 
in all time periods was settled and used for the exploitation of the rich gold deposits.

Today gold mining is a major activity in the middle reaches of the valleys of Palpa. With simple tools and dynamite, informal miners exploit the gold deposits of the fairly rich veins of the NascaOcoña belt. A major location for gold processing is
Saramarca, in the Viscas valley, where nowadays the minerals are crushed in simple stone mills, washed with water and extracted with mercury (Schulz 2007; Stöllner 2011; Stöllner and Reindel 2007).

The mines in the Nasca-Ocoña-belt were quite small. No large mine like the mina Primavera in the Ingenio valley (see Vaughn et al. 2012 in this

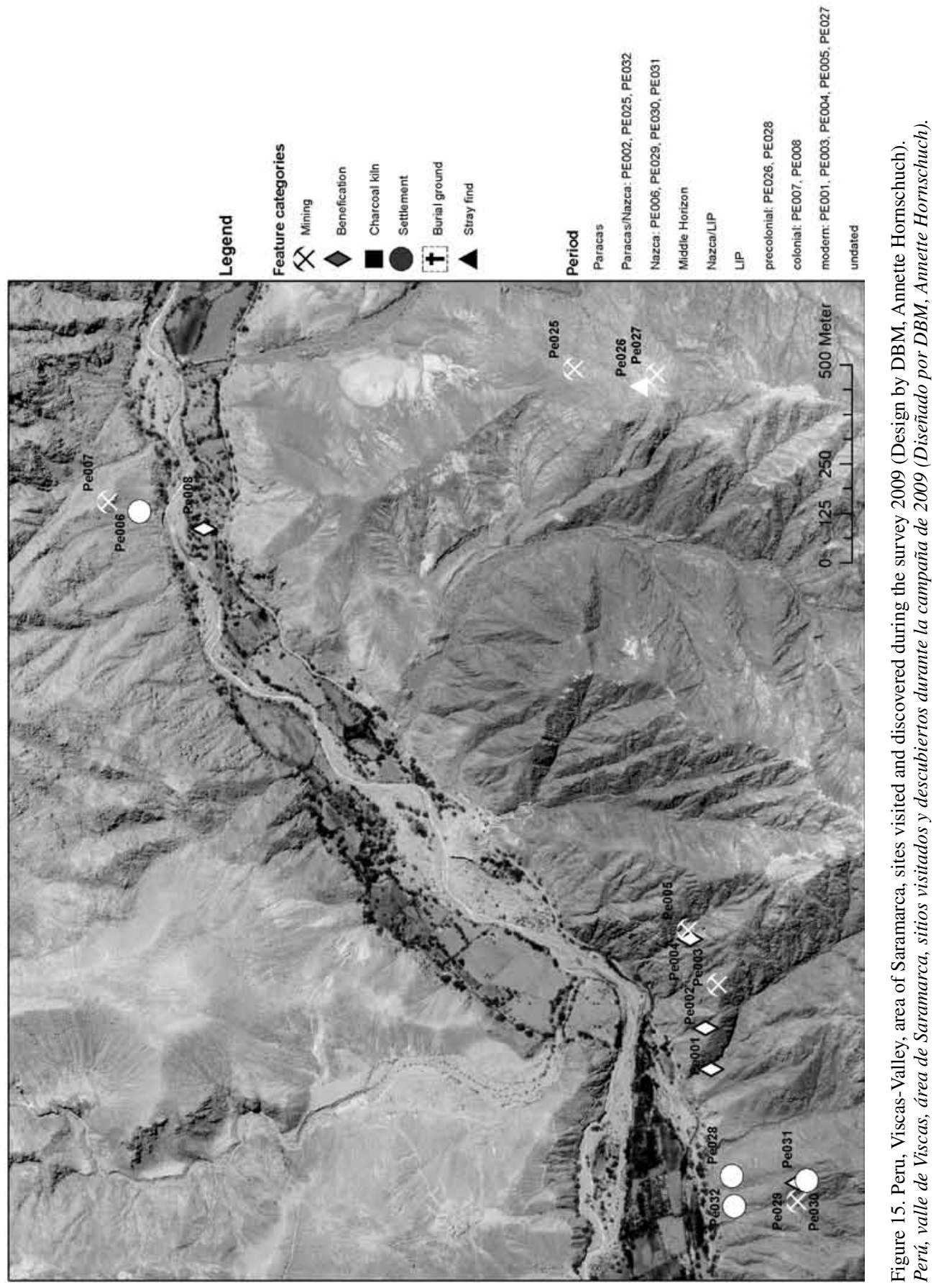




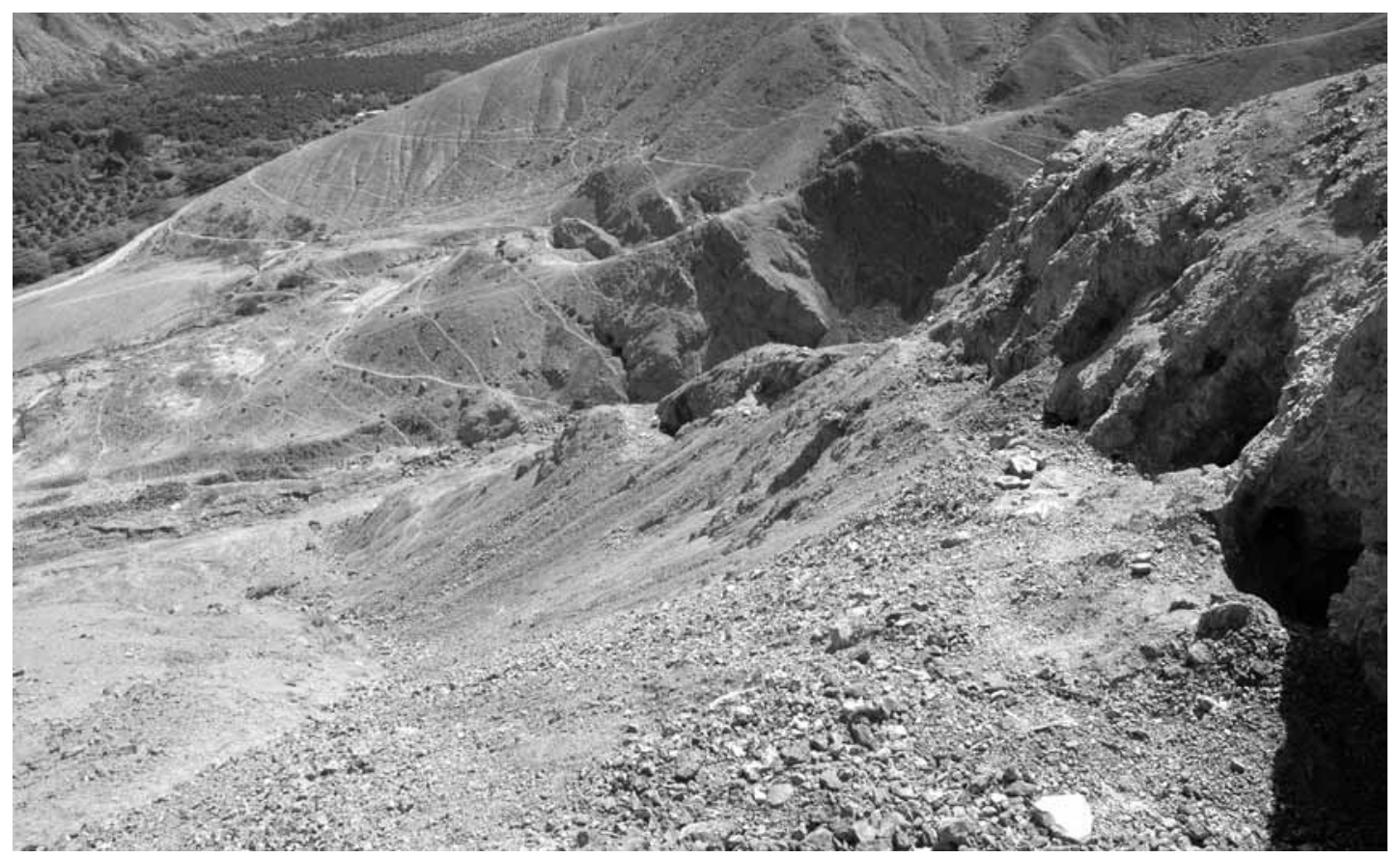

Figure 16. Peru, Mollaque Grande, Precolonial and sub-modern gold exploitation alongside the mineralisation zone (Foto by DBM, Th. Stöllner). Perú, Mollaque Grande, Explotación aurífera prehispánica y subactual junto a la zona mineralizada (Foto de DBM, Th. Stöllner).

issue) has been detected so far. Many smaller mines from different time periods, however, suggest a long-lasting tradition of mining in the region. The different types of evidence for mining activities include horizontal and vertical pits, tailings of mining activities, mining tools and local processing areas of the ores. It is not always clear if ancient mines and quarries in the Palpa area are associated with pre-Columbian operations or date to colonial times. Modern quarries, however, can easily be recognized by the traces of fresh cuts or metal tools being used. Ancient mines have associated remains of ceramic artifacts, mining tools like simple stone hammers and a set for beneficiating the ores (Figure 19). The ores and minerals extracted from the different deposits generally were processed in a preliminary way at places close to the mines and quarries. In some cases these processing places were directly associated with ancient settlements. What is somehow surprising is the fact that fire-setting could not be observed in a single case: This may be the reason why larger quantities of stone hammers -which are so typical for exploitations method of this kind- cannot be found. It should be stressed that so far no prove for fire-setting could be dated to pre-Columbian times in the Andean regions (e.g. Shimada and Craig 2012 in this issue; Stöllner 2011).

In the case of lithic material we found the debris of the processed material and unused halffinished products.

\section{Geochemical Analyses of Ores, Metals and Minerals}

The first results of the geochemical analysis of the obsidian samples allow us to trace the sources of the obsidian that was used in Palpa. During our field survey in 2009 we visited the open pit obsidian quarry in the Altiplano region near Huanca Sancos called Jichja Parco (Stöllner 2011). N. Tripcevich and D. Contreras, who had visited and mapped this site as well, demonstrated that Jichja Parco is part of the greater flow of obsidian that has been known as Quispisisa, and that it had to be viewed as the main supplier for obsidian in the South of Peru (Tripcevich and Contreras 2011).

Obsidian samples from 18 securely dated archaeological sites of the Andean Transect research area, as well as four samples from the obsidian quarry site Jichja Parco were chemically 
analysed, in order to determine the provenance and locate the raw material sources used by the people living in the Andean Transect area in different time periods. Neutron Activation Analysis (NAA) (Glascock et al. 2007; Kuleff and Djingova 1990; Mommsen 1986), which is commonly used to determine the provenance of obsidian especially in South America and Peru (Glascock et al. 2007), enabled us to characterize the trace elements of the Obsidian samples and to compare our results with the published sources. The measurements are performed by three high purity germanium detectors (HPGe, Ortec) at the Curt-EngelhornCenter for Archaeometry (Mannheim, Germany). The best results to determine the origin of obsidian were achieved with the trace elements Hf, Cs, $\mathrm{Th}, \mathrm{Fe}$ and $\mathrm{Rb}$ (e.g. Glascock et al. 2007). Inter alia we used the trace element concentrations of $\mathrm{Hf}$ (ppm) and Cs (ppm), in combination with the data for the archaeologically important obsidian
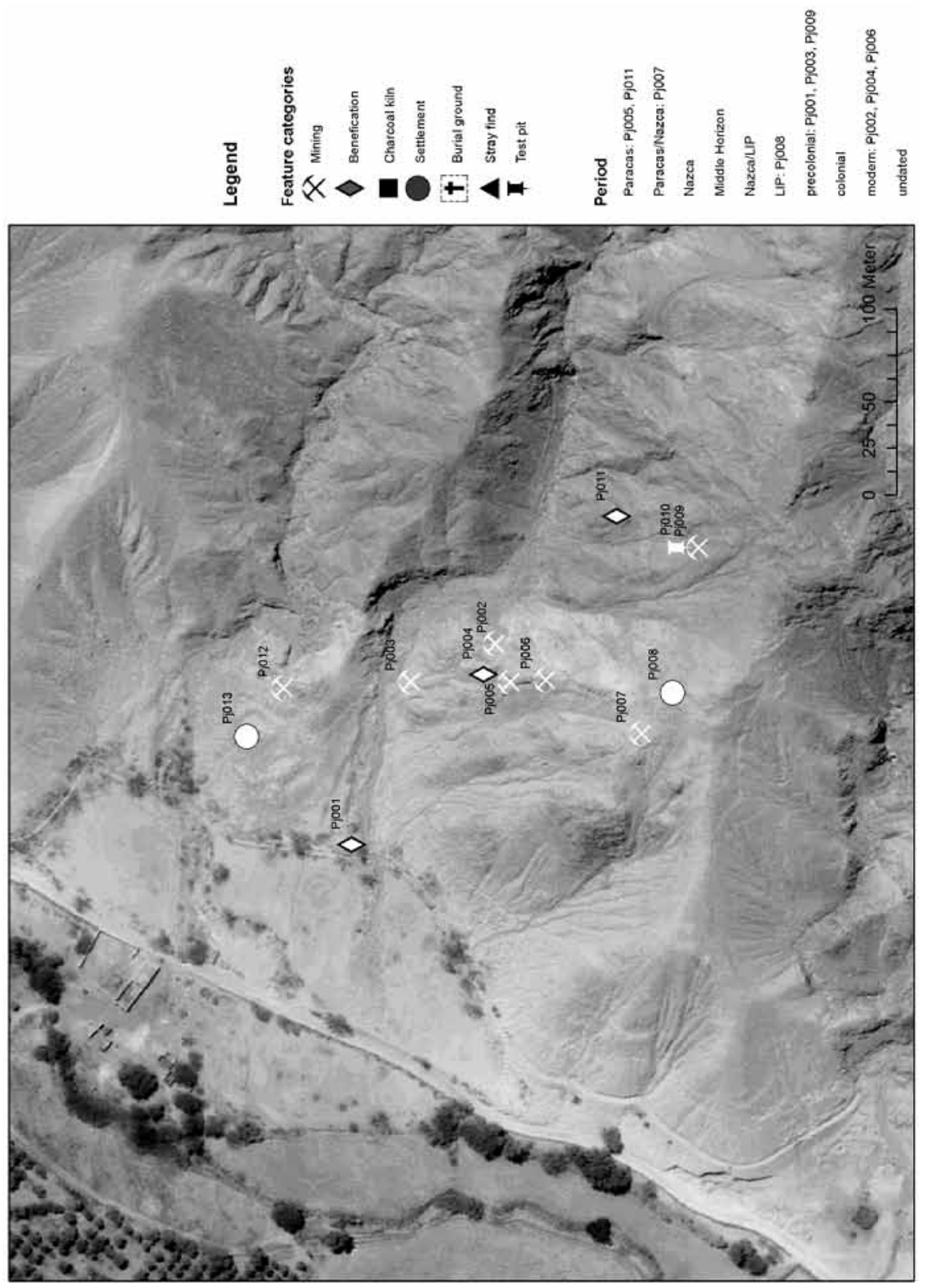


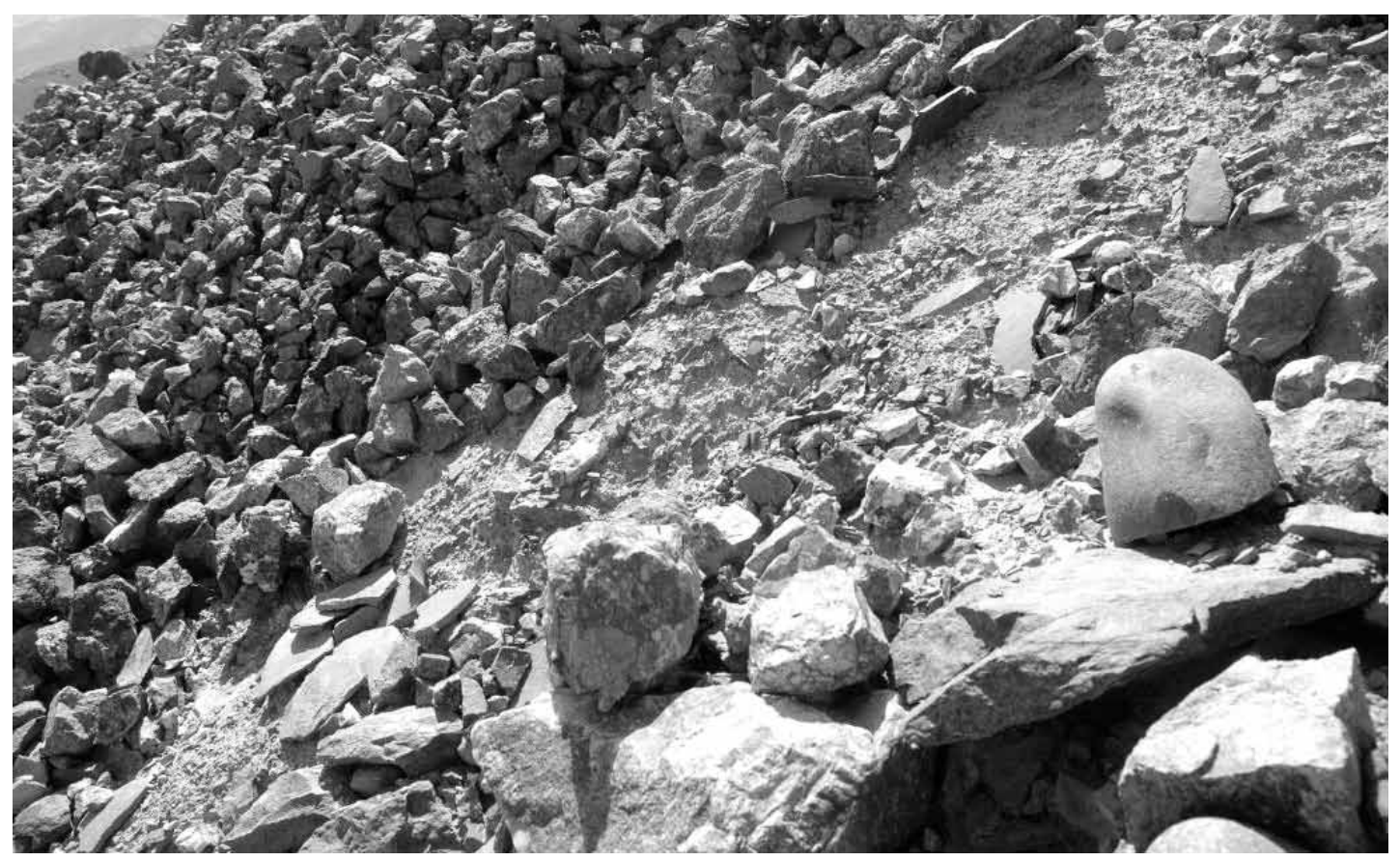

Figure 18. Mollaque Grande. Superposition of a sub-modern mining dump over ancient mining tailing characterized by prehispanic stone tools and ceramic sherds.

Mollaque Grande. Superposición de un desmonte subactual sobre un desmonte minero antiguo caracterizado por herramientas de piedra y fragmentos cerámicos.
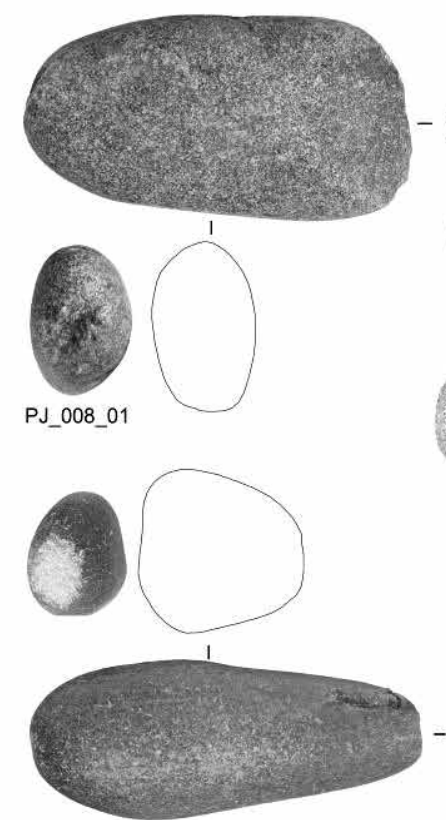

PJ_008_03
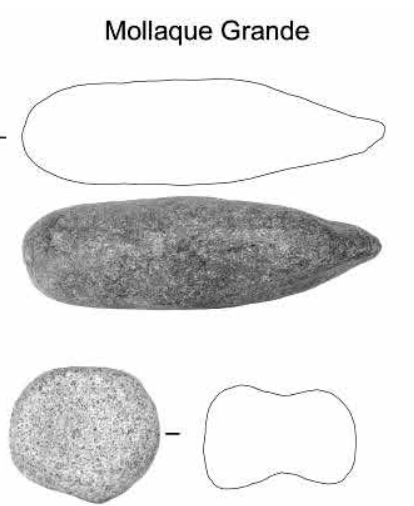

PJ_003_01
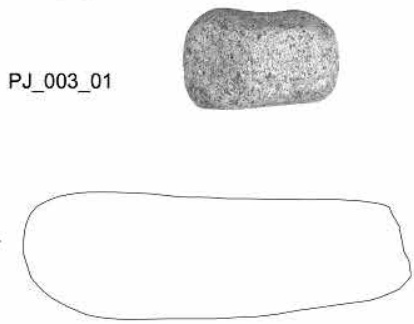

ang

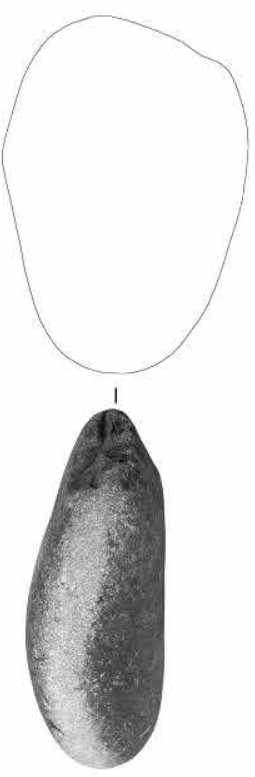

PJ_008_02

Figure 19. Mollaque Grande. Mortars, hammerstones and pestles used for mining activities (Fotos/Design by DBM, B. Gräfingholt).

Mollaque Grande. Morteros, martillos líticos y percutores utilizados en actividades mineras (Fotos/Diseño de DBM, B. Gräfingholt). 
quarries in southern Peru provided by Glascock et al. (2007) to pinpoint the origin of our obsidian flak samples. As shown in Figure 20 every single sampled obsidian quarry in southern Peru has a significant trace element concentration of $\mathrm{Hf}$ and Cs, which enhanced us to clearly locate the origin of our samples. The results of the $\mathrm{Hf}$ and Cs relations presented in Fig. 20 indicate that all but one flake from the Later Intermediate site Chillo fall within the chemical group defined as Quispisisa and more precisely Jichja Parco. Our results confirm the hypothesis of N. Tripcevich and D. Contreras that Jichja Parco is the main quarry used in the central Andean region (Tripcevich and Contreras 2011). We proved that the Palpa region used the Jichja Parco source as main supplier for Obsidian throughout the archaic up to the Middle Horizon. The LIP seemed to alter the trade routes and used other sources of obsidian which were farther away than Jichja Parco. A similar conclusion was reached for the Chivay obsidian source where obsidian procurement declined during the Late Intermediate Period (Tripcevich 2009).

First results of compositional analysis of samples extracted from modern and ancient mines in the Palpa region show surface near oxides and carbonides with high enrichments in copper and gold (up to $100 \mathrm{~g}$ per ton) (Figure 21). In pre-Columbian times more small but highly enriched veins, also called "bonanzas", existed and have typically been exploited in earlier stages of metallurgy. This resembles the general picture that we obtained from the excavation finds. Metal objects are mainly made of gold and copper or alloys of both materials.

First results of portable X-ray fluorescence spectrometry analysis of different metal artifacts from Nasca to LIP-horizon provided us with first insights to the composition of some metals; later the same samples were re-measured by help of the Bochum and Frankfurt MC-ICP-MS (inductively coupled plasma Mass spectrometry) (Figure 21). The diagram shows, that the copper and silver/

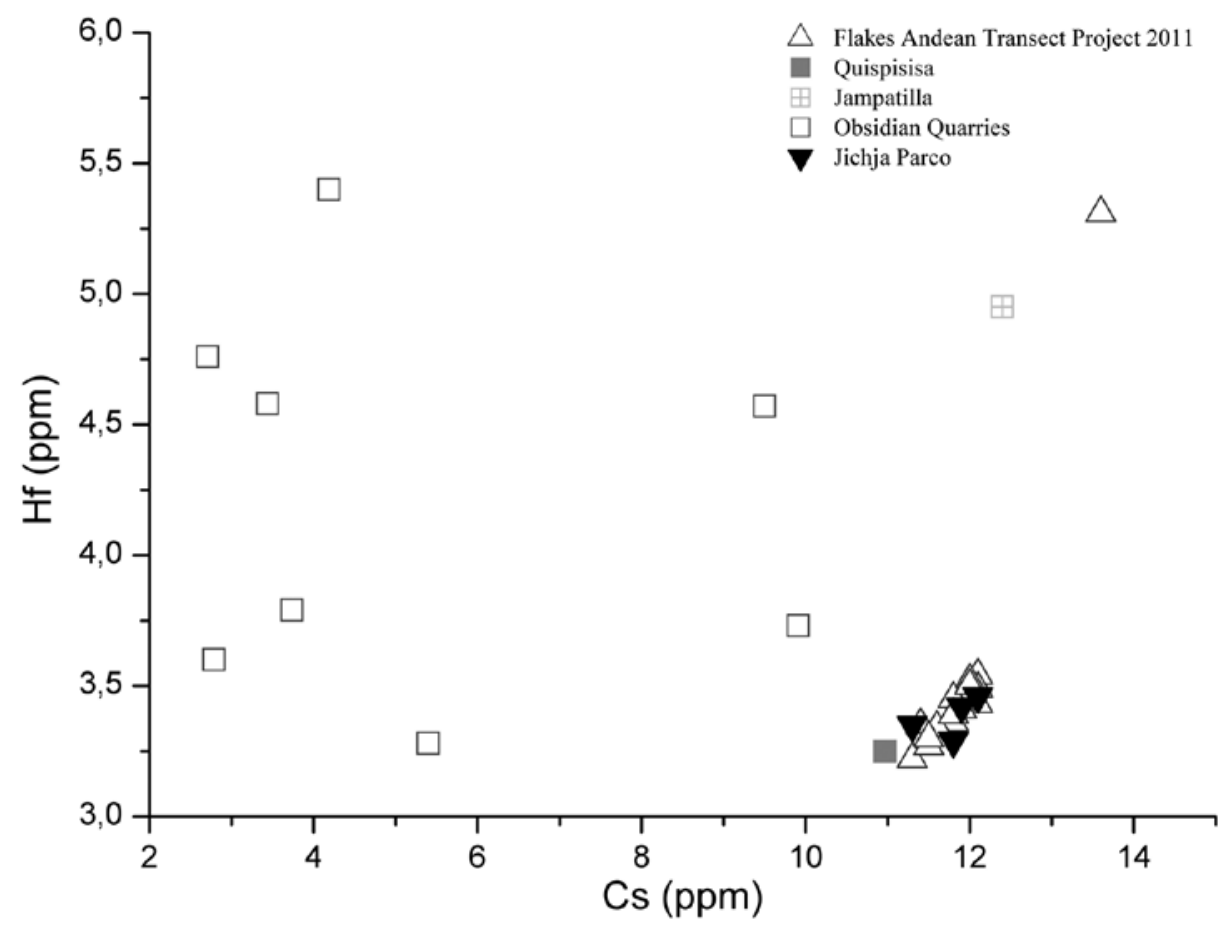

Figure 20. Bivariate plot of Cs versus Hf for obsidian flakes from the Andean Transect Project and Jichja Parco source. Element concentration of Cs and Hf for the Obsidian Quarries (Alca 1, Alca 2, Alca 3, Chivay, Puzolana, Potreropampa, Lisahuacho, Aconcahua), Quispisisa and Jampatilla are taken from Glascock et al. 2007 (Design by DBM, B. Gräfingholt).

Gráfico bivariado de Cs versus Hf para lascas de obsidiana del proyecto Andean Transect y de la fuente de Jichja. Concentración elemental de Cs y Hf para las canteras de obsidiana (Alca 1, Alca 2, Alca 3, Chivay, Puzolana, Potreropampa, Lisahuacho, Aconcahua), Quispisisa y Jampatilla fueron tomadas de Glascock et al. 2007 (Diseñado por DBM, B. Gräfingholt). 


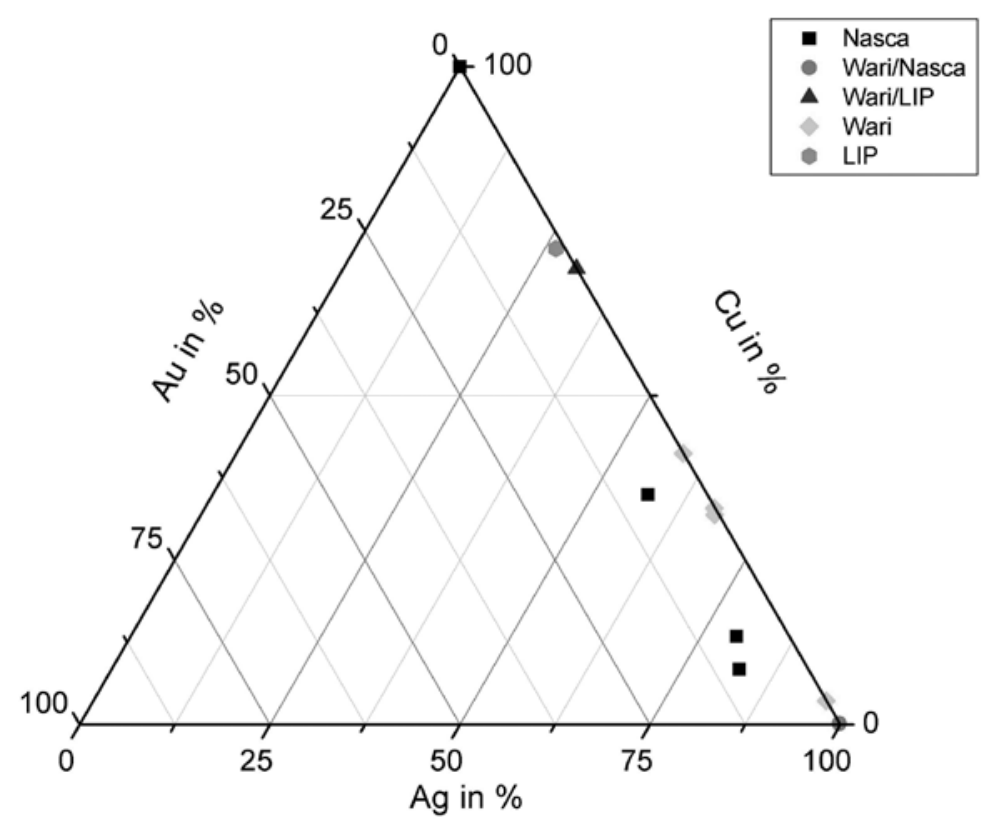

Figure 21. Results of SC-ICP-MS compositional analysis of some archaeological metal objects recovered in the research area (Design by DBM, B. Gräfingholt).

Resultados de análisis composicionales por SC-ICP-MS de algunos objetos metálicos encontrados en el área de estudio (Diseñado por DBM, B. Gräfingholt).

gold alloys from the Nasca-period are typical for the metal ores that could be expected from the Nasca-Ocoña formation: One pure copper artifact from Altiplano site Botiqiriayoq may derive from a primary native copper deposit and could therefore even been transported from the coastal areas to the Altiplano. But this needs further approval by a larger data-base.

The Middle Horizon artifacts, however (Figure 21) are copper arsenide alloys with silver from deposits which seem typical for Northern Peru or the Lake Titicaca region; such ores are not known in the Nasca-Ocoña formation. The silver of one sample from Lucriche may derive from silver rich ores (cerussites). It is interesting that the only tin bronze analyzed so far comes from the Montegrande site at the river-banks of the Rio Grande within the coastal cordillera. Based on the abundance of surface finds of precious materials like metal objects and Spondylus shells and artifacts, as well as the amount of llama bones, it is assumed that Montegrande was an important trading post between the coastal and the highland regions from the Paracas to the Late Intermediate Period. The tin bronze therefore fits into such a pattern and shows that a clear division between tin bronze spheres and arsenical bronze spheres in the Andean region could have be broken by long distance trade. Furthermore this artifact highlights that in contrast to the previously postulated "linea divisoria del bronce" by Lechtman and MacFarlane (2006:506) tin bronze artifacts can be documented north of the postulated border.

Most of the ore samples have been analyzed in laboratories of the German Mining Museum in Bochum with ICP-OES (inductively coupled plasma optical emission spectrometry). The method allows to detect up to 70 chemical elements on the level of trace elements and to determine their quantities. The metal ores from the Nasca-Ocoña geological formation show surface near oxides and carbonides with high enrichments in copper (e.g. PAP 12: 20\% of copper) and gold (up to $105 \mathrm{~g}$ per ton) (Table 1). The given concentration points to small but highly enriched "bonanzas".

A selection of some of the ores was investigated also with MC-ICP-MS (inductively coupled plasma mass spectrometry) to determine the lead-isotopes (Klein et al. 2009). The latter investigations are currently carried out in collaboration with the 
Table 1. Results of ICP-OES Compositional analysis of copper and gold concentrations of ore samples recollected from mining places in the research area (Design by DBM, G. Gassmann).

Resultados de análisis composicionales ICP-OES de concentraciones de cobre y oro de muestras minerales colectadas en distritos mineros del área de estudio (Diseñado por DBM, G. Gassmann).

\begin{tabular}{ccccccc}
\hline Proben & $\mathrm{SiO}_{2}$ in $\%$ & $\mathrm{AI}_{2} \mathrm{O}_{3}$ in $\%$ & $\mathrm{Fe}_{2} \mathrm{O}_{3}$ in $\%$ & $\mathrm{Cu}$ in $\%$ & $\mathrm{Ag}$ in $\%$ & $\mathrm{Au}$ in $\%$ \\
\hline PA 12 & 80,2 & 1,34 & 8,15 & 3,97 & 0,0002 & 0,0101 \\
PC 01 & 67,9 & 2,77 & 12,97 & 3,5 & 0,0002 & 0,0149 \\
PC 02 & 94,2 & 0,64 & 1,23 & 0,0063 & 0,0006 & 0,0013 \\
PC 07 & 90,0 & 2,27 & 2,34 & 0,2365 & 0,0012 & 0,0071 \\
PC 14 & 10,6 & 3,06 & 24,16 & 2,96 & 0,00004 & 0,0038 \\
PD 01 & 32,3 & 0,20 & 26,35 & 18,37 & 0,0002 & 0,0418 \\
PD 04 & 38,7 & 13,15 & 29,57 & 2,03 & 0,0005 & 0,0057 \\
PD 17 & 9,9 & 2,23 & 75,45 & 1,54 & 0,00006 & 0,0148 \\
PE 01 & 28,0 & 1,72 & 62,88 & 1,2 & 0,0009 & 0,0304 \\
PE 06 & 98,1 & 0,04 & 1,60 & 0,0096 & 0,0082 & 0,1051 \\
PE 25 & 91,9 & 0,39 & 4,25 & 0,1372 & 0,0002 & 0,0011 \\
PH 02 & 89,2 & 4,59 & 2,59 & 0,9730 & 0,0003 & 0,0013 \\
PJ 01 & 68,2 & 6,30 & 10,80 & 4,68 & 0,00013 & 0,0034 \\
PE 29 & 75,7 & 1,00 & 21,78 & 0,0919 & 0,0002 & 0,0024 \\
\hline
\end{tabular}

University of Frankfurt (S. Klein). According to older results made by E. Pernicka (Pernicka 1995) we believe the discussion of both the lead-isotopes and the trace elements are indispensable for a clear detection of metal artifact provenances. As far as the small sample-series allows a first statement, there is a characteristic isotopic pattern of the southern Peruvian coastal area that even overlaps also with some of the silver-copper artifacts found during the excavations and surveys in the highlands. The isotopic variation separates clearly Northern Coastal and Central Peruvian ore samples (Lechtman 1991), but also colonial silver objects and coins produced from Potosí silver bearing ores (Desaulty et al. 2011) (Figures $22 \mathrm{a} / \mathrm{b}$ ). A rough evaluation indicates a further south Peruvian ore field not yet sufficiently investigated (Lechtman and Mac Farlane 2005, 2006). It should be mentioned that some of the ores investigated from the Nasca-Ocoña formation nicely matches with silver-copper alloys from the highland sites of the Palpa survey. While the data processing of the Palpa samples is not completed yet, no further evaluation is possible at the moment. However, there is undoubtedly still a high potential for a continuation in analyzing metals by these methods in southern Peru.

Secondary copper minerals like malachite, chrysocolla and turquoise were used in Palpa from archaic times on. The use of turquoise objects in Palpa is especially interesting. According to previous studies, no turquoise deposit has been identified so far in the Central Andes (see above). It is believed that turquoise was imported from outside the Central Andean area.

In a study based on geochemical analysis of museum and excavation materials, however, the German geologist Hans Ruppert postulated in 1982 the presence of a hitherto unrecorded turquoise deposit in southern Peru (Ruppert 1982, 1983). In Palpa several small turqouise deposits were identified by our collaborator, the geologist Ulrich Glasmacher from Heidelberg University. It is therefore possible that Palpa or the Nasca region in general was one of the sources of Peruvian turquoise.

\section{Summary and Conclusions}

Summing up the preliminary results of our investigation about mining and quarrying activities in the valleys of Palpa, we can state that we detected several places related to the extraction and the processing of lithic material, ores and minerals in pre-Columbian times. All places detected so far are locations with evidence of small scale mining. It is also important to point out that so far we have not found any smelting place or any furnaces where the ores may have been smelted.

The available evidence demonstrates, however, that lithic materials, minerals and ores were produced and moved along the Andean Transect since the earliest periods of pre-Columbian occupation of the region. Obsidian was transported 

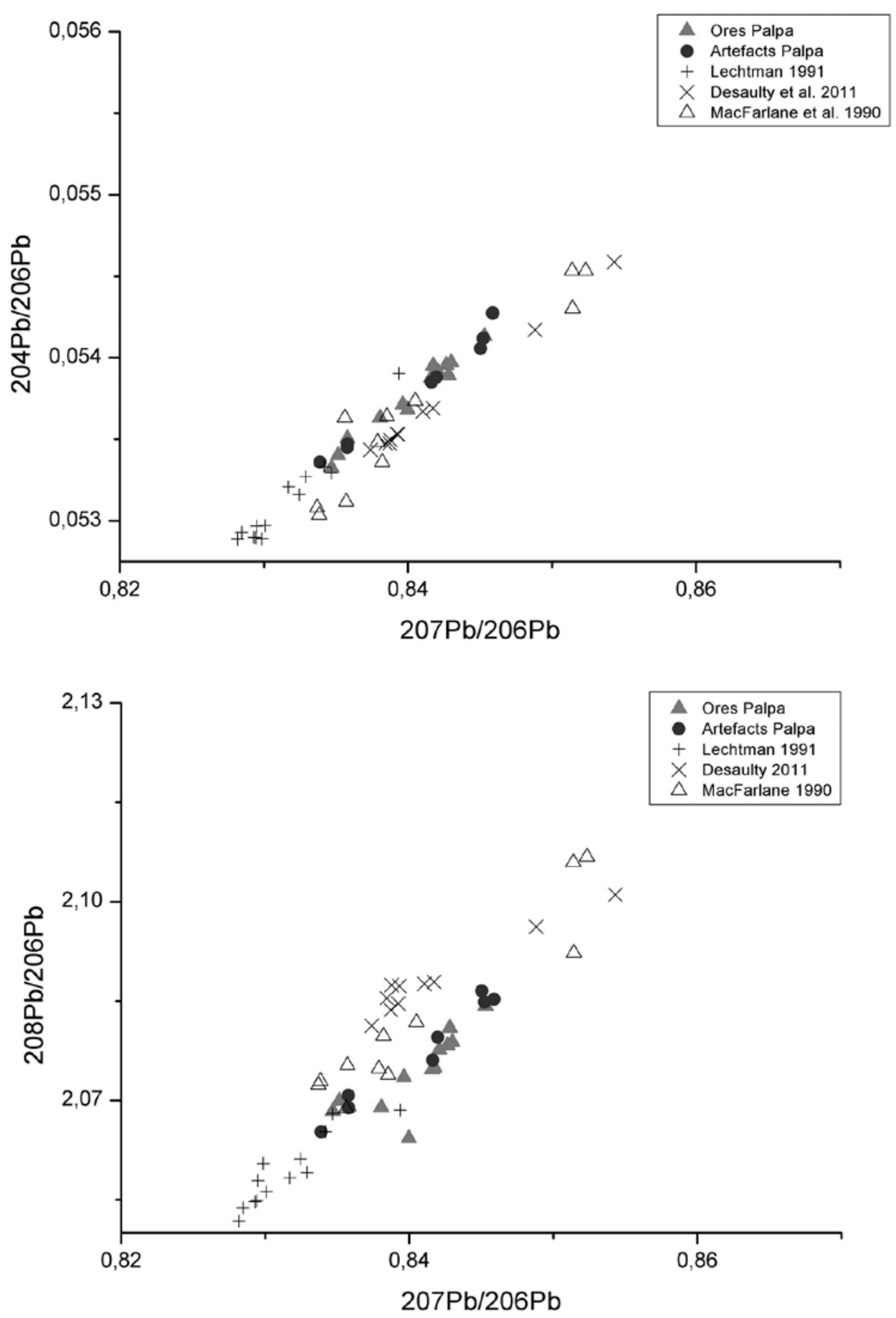

Figure 22. Lead isotope data from some metal objects from the Palpa highland Survey in comparison to data from central and northern Peruvian ore sources (data from Lechtman 1991), from ores of the Central Andes (data from MacFarlane et al. 1990) and from colonial silver objects and coins produced from ores of northern Bolivia (Potosí) (data from Desaulty et al. 2011) (Design by DBM, B. Gräfingholt).

Resultados de isótopos de plomo de algunos objetos metálicos provenientes de la prospección de las tierras altas de Palpa en comparación con resultados de fuentes minerales del centro y norte peruano (Lechtman 1991), de minerales de los Andes Centrales (MacFarlane et al. 1990) y de objetos de plata y monedas coloniales producidos a partir de minerales del norte de Bolivia (Potosí) (Desaulty et al. 2011) (Diseñado por DBM, B. Gräfingholt). 
to the coast since the archaic period and can be considered as an evidence of the mobility of the earliest settlers. Gold is present in the region at least since the Early Paracas period. In part, the gold was produced locally, but some of the gold was also imported from the north (Schlosser et al. 2009). The small number of known Paracas gold objects shows that these were rare and precious items, just as in other regions of the Central Andean Area in the Early Horizon.

This situation changed obviously in late Paracas and Nasca times. It is clear that many of the goldand copper extraction sites have been used for the first time during this period. This speaks for a considerable increase in metal use in general. Nasca Gold objects are present in many museum and private collections. The objects found in the elite tombs of La Muña show that gold played an integral role in the upper class of Nasca society. In the Nasca period the use of copper also begins. The associated Nasca ceramic sherds at nearly every pre-Columbian mining place that we identified during our surveys may indicate increased mining activities in the Nasca period.

While in Nasca times clearly gold was the favoured ore to be mined, in the Middle Horizon mining and metallurgy of copper ores dominated. Copper objects were found particularly in the highlands. Due to the presence of rich deposits of copper in the NascaOcoña belt, however, it is possible that the mines in this region constituted part of the sources from where the raw material was transported to the highlands.

Copper and gold production continued into the Late Intermediate Period, a period when the whole research area of the Andean Transect was repopulated after a time of nearly complete abandonment.

Acknowledgements: Funding for this research has been provided by the Federal German Ministry for Education and Research (BMBF) and the German Research Foundation (DFG). The mining surveys took place in March and April 2009 and were accompanied by the authors and Dr. Ch. Dekant (Munich), P. Segura (Palpa) and Prof. Dr. G.A. Wagner (Heidelberg). Thanks to Johny Isla Cuadrado the ceramic finds were dated according to the detailed chronology of the Palpa-project; additional thanks to Annette Hornschuch and Stefanie Menic for their assistance in preparing the maps. Thanks to the laboratory of the DBM, especially Dr. Michael Bode, Dipl. Min. Dirk Kirchner, and Dr. Michael Prange as well as PD Dr. Sabine Klein at the University of Frankfurt and the Laboratories of the CEZ Mannheim (Prof. Dr. E. Pernicka, Dr. J. Lutz).

\section{References Cited}

Benfer, R. 1999. Proyecto de excavaciones en Paloma, Valle de Chilca, Perú. Boletín de Arqueología PUCP 3:213-237.

Burger, R.L. and F. Asaro 1979. Análisis de los rasgos significativos en la obsidiana de los Andes. Revista del Museo Nacional 43:281-326.

Burger, R.L. and M.D. Glascock 2000. Locating the Quispisisa Obsidian source in the Department of Ayacucho, Peru. Latin American Antiquity 11:258-268.

Burger, R.L, K.L. Mohr Chavez and S.J. Chavez 2000. Through the glass darkly: Pre-Columbian obsidian procurement and exchange in southern Peru and Northern Bolivia. Journal of World Prehistory 14:267-362.

Desaulty, A.-M., Ph. Telouk, E. Albalat and F. Albarède 2011. Isotopic $\mathrm{Ag}-\mathrm{Cu} \_\mathrm{Pb}$ resord of silver circulation through $16^{\text {th }}-18^{\text {th }}$ century Spain. Proceedings of the National Academy Sciences 108/22:9002-9007.

Eerkens, J.W., K.J. Vaughn and M. Linares Grados 2009. Pre-Inca mining in the Southern Nasca Region, Peru. Antiquity 83:738-750.

Eitel, B. and B. Mächtle 2009. Man and Environment in the Eastern Atacama Desert (Southern Peru): Holocene Climate Changes and Their Impact on Pre-Columbian Cultures. In New
Technologies in Archaeology. Multidisciplinary Investigations in Nasca and Palpa, Peru, edited by M. Reindel and G.A. Wagner, G. A. Springer, pp. 17-37. Heidelberg, Berlin.

Eitel, B., S. Hecht, B. Mächtle, G. Schukraft, A. Kadereit, G.A. Wagner, B. Kromer, U. Unkel, and M. Reindel 2005. Geoarchaeological evidence from desert loess in the Nazca-Palpa region, southern Peru: Palaeoenvironmental changes and their impact on Pre-Columbian cultures. Archaeometry 47(1):137-158.

Engel, F.A. 1966. Geografía Humana Prehistórica y Agricultura Precolombina de la Quebrada de Chilca. Departamento de Publicaciones, Universidad Agraria, Lima.

- - - 1980. Paloma village 613: A 6000 year old "fog oasis" village in the Lower Central Andes of Peru. In: Prehistoric Andean Ecology. Man, Settlement and Environment in the Andes, edited by F.A. Engel, pp. 103-135. Papers of the Department of Anthropology, Hunter College of the City University of New York, New York.

- - - 1988. Ecología prehistórica andina. El hombre, su establecimiento y el ambiente de los Andes. In La Vida en Tierras Áridas y Semiáridas. Chilca, Pueblo 1. Implementos de Hueso, C.I.Z.A., Lima. 
Figueroa, V., H. Salinas, D. Salazar, G. Manriquez and P. Nuñez-Regueiro 2010. Prehispanic hammerstones from the Atacama Desert: Antofagasta Region, North of Chile. In Mining in European History and its Impact on Environment and Human Societies. Proceed, edited by P. Anreiter, P., G. Goldenberg, K. Hanke, R. Krause, W. Leitner, F. Mathis,K. Nicolussi, K. Oeggl, E. Pernicka, M. Prast, J. Schibler, I. Schneider, H. Stadler, Th. Stöllner, G. Tomedi, P. Tropper (Hrsg.), pp. 335-338. Innsbruck University Press, Innsbruck.

Glascock, M.D., R.J. Speakman, and R.L. Burger 2007. Sources of Archaeological Obsidian in Peru. Descriptions and Geochemistry. In Archaeological Chemistry. Analytical Techniques and Archaeological Interpretation, edited by M. Glascock, pp. 522-552. ACS symposium series 968, Washington, DC.

González, C. and C. Westfall 2005. Consideraciones sobre la prehistoria de Atacama: El Salvador y sus aportes locales e interregionales. Boletín de la Sociedad Chilena de Arqueología 38:53-70.

- - - 2008. Atacameños en El Salvador: Nuevas apreciaciones sobre un fardo funerario del Cementerio Las Turquesas. Estudios Atacameños 35:49-73.

Isla Cuadrado, J. 2009. From hunters to regional lords: Funerary practices in Palpa, Peru. In New Technologies in Archaeology. Multidisciplinary Investigations in Nasca and Palpa, edited by M. Reindel and G.A. Wagner, pp. 119-139. G. A. Springer, Heidelberg, Berlin.

Isla Cuadrado, J. and M. Reindel 2006a. Una tumba Paracas Temprano en Mollake Chico, valle de Palpa, costa sur del Perú / Ein Grab der frühen Paracas-Zeit in Mollake Chico, Palpa-Tel, Südküste Perus. Zeitschrift für Archäologie Außereuropäischer Kulturen 1:153-181.

Isla Cuadrado, J. and M. Reindel 2006b. Burial patterns and sociopolitical organization in Nasca 5 society. In Andean Archaeology III: North and South, edited by W. Isbell and H. Silverman, pp. 374-400. Blackwell, Malden, MA.

Klein, S., C. Domergue, Y. Lahaye, G.P. Brey and H.-M. von Kaenel 2009. The lead and copper isotopic composition of copper ores from the Sierra Morena (Spain). Journal of Iberian Geology 35: 59-68.

Kuleff, I. and R. Djingova 1990. Activation analysis in archaeology. In Activation Analysis 2, edited by Z. Alfassi, pp. 427-489. CRC-Press Inc., Boca Raton, Florida.

Kuramoto, J. 2001. La Minería artesanal e informal en el Perú. In: Minerals and Sustainable Development 82, pp. 1-53. International Institute for Environment and Development, Lima.

Lechtman, H. 1976. A metallurgical site survey in the Peruvian Andes. Journal of Field Archaeology 3:1-42.

- - - 1991. The production of copper-arsenic alloys in the Central Andes: Highland ores and coastal smelters. Journal of Field Archaeology 18:43-76.

Lechtman, H. and A.W. Macfarlane 2005. La metalurgia del bronce en los Andes Sur Centrales: Tiwanaku y San Pedro de Atacama. Estudios atacameños 30:7-27.

- - - 2006. Bronce y redes de Intercambio andino durante el Horizonte Medio: Tiwanaku y San Pedro de Atacama. In Esferas de interacción prehistóricas y fronteras nacionales modernas, Institute of Andean Research, Lima, pp. 503-539.

Lothrop, S. K. 1937. Gold and silver from southern Peru and Bolivia. Journal of the Royal Anthropological Institute of Great Britain and Ireland 67: 305-325.

- - - 1951. Gold artifacts of Chavin style. American Antiquity 3:226-240

MacFarlane, A. W., P. Marcet, A. P. LeHuray, and U. Petersen. 1990. Lead Isotope provinces of the Central Andes inferred from ores and crustal rock. Economic Geology 85: 1857-1880.

Mommsen, H. 1986. Archäometrie. Neuere naturwissenschaftliche Methoden und Erfolge in der Archäologie. Teubner, Stuttgart

Núñez Atencio, L. 1999. Valoración minero-metalúrgica circumpuneña: Menas y Mineros para el lnka rey. Estudios Atacameños 18:177-221.

Pernicka, E. 1995. Gewinnung und Verbreitung der Metalle in prähistorischer Zeit. Jahrbuch des RGZM 37(1): 21-129.

Petersen, G. 1970. Minería y Metalurgia en el Antiguo Perú. Arqueológicas 12. Museo Nacional de Antropología y Arqueología, Lima.

Petersen, U. 1979. Metallogenesis in South America: Progress and Problems. Episodes 4:3-11.

- - - 1989. Geological Framework of Andean Mineral Resources. In Geology of the Andes and its Relation to Hydrocarbon and Mineral Resources, edited by G. E. Ericksen.

M.T. Cañas Pinochet and J.A. Reinemund, pp. 213-232. Tulsa, Oklahoma.

Reindel, M. 2009. Life at the edge of the desert. Archaeological reconstruction of the settlement history in the valleys of Palpa, Peru. In: New Technologies in Archaeology. Multidisciplinary Investigations in Nasca and Palpa, edited by M. Reindel and G.A. Wagner, pp. 439-462. G.A. Springer, Heidelberg, Berlin.

- _ - 2010. Archäologische Forschungen der Jahre 2007 und 2008 im Anden-Transsekt, Süd-Peru. Zeitschrift für Archäologie Außereuropäischer Kulturen 3:207-224.

Reindel, M. and J. Isla 2001. Los Molinos und La Muña. Zwei siedlungszentren der Nasca-Kultur in Palpa, Südperu. Beiträge zur Allgemeinen und Vergleichenden Archäologie 21:241-319.

- - - 2006. Culturas tempranas de la costa sur del Perú: sus evidencias en los valles de Palpa. Boletín de Arqueología PUCP 10:237-284.

Reindel, M. and G.A. Wagner 2009. New Technologies in Archaeology. Multidisciplinary Investigations in Nasca and Palpa, edited by G.A. Springer, Heidelberg, Berlin.

Root, W. 1949. The metallurgy of the Southern Coast of Peru. American Antiquity 15:10-37.

Ruppert, H. 1982. Zur verbreitung und herkunft von türkis und sodalith in präkolumbischen kulturen der kordilleren. Baessler Archiv 30:69-124.

Root, W. 1983. Geochemische untersuchungen an türkis und sodalith aus lagerstätten und präkolumbischen kulturen der kordilleren. Berliner Beiträge zur Archäometrie 8: 101-210.

Salazar, D. 2008. La producción minera en San José del Abra durante el Periodo Tardío atacameño. Estudios Atacameños 36:43-72. 
Schlosser, S., R. Kovacs, E. Pernicka, D. Günther and M. Tellenbach 2009. Fingerprints in gold. In New Technologies in Archaeology. Multidisciplinary Investigations in Nasca and Palpa, edited by M. Reindel and G.A. Wagner, pp. 409-436. G. A. Springer, Heidelberg, Berlin.

Schulz, G. 2007. Kleinstbergbau auf gold im gebiet von Palpa/ Peru. World of Mining 1:41-47.

Stöllner, T. 2009. Gold in southern Peru? Perspectives of research into mining archaeology. In New Technologies in Archaeology. Multidisciplinary Investigations in Nasca and Palpa, edited by M. Reindel and G.A. Wagner, pp. 393-407. G. A. Springer, Heidelberg, Berlin.

- - - 2011. Präkolumbischer bergbau in den Anden. In Schätze der Anden-Chiles Kupfer für die Welt, edited by R. Slotta, pp. 181-212. Exhibition catalogue, Bochum.

Stöllner, T. and M. Reindel 2007. Vorspanische goldgewinnung im bereich von Palpa-Nasca? Bericht über eine einwöchige prospektionskampagne an der Südküste Perus. Der Anschnitt 59(1): 2-12.

Stöllner, T., G. Körlin, G. Steffens and J. Cierny (eds.). 2003. Man and Mining. Studies in honour of Gerd Weisgerber. Der Anschnitt, Beiheft 16, Bochum.

Stöllner, T., I. Gambaschidze and A. Hauptmann 2008. The earliest gold mining of the ancient world? research on an Early Bronze Age gold mine in Georgia. In Ancient Mining in Turkey and the Eastern Mediterranean, edited by Ü. Yalcin, H. Özbal, A.G. Pasamehmetoglu, pp. 271-288. AMITEM, Ankara.

Tello, J.C. 1959. Paracas-primera parte. Institute of Andean Research, Lima.

Tello, J.C. and T. Mejía Xesspe 1979. Paracas, segunda parte: Cavernas y Necrópolis. Universidad Nacional Mayor de San Marcos, Lima.

Tripcevich, N. 2009. Exotic goods, chivay obsidian, and sociopolitical change in the South-Central Andes. In Trade and Exchange. Archaeological Studies from History and Prehistory, edited by C.D. Dillian, C.L. White, pp. 59-74. Springer, New York.

Tripcevich, N. and D. A. Contreras 2011. Quarrying evidence at the Quispisisa Obsidian source, Ayacucho, Peru. Latin American Antiquity 22: 121-136.

Uhle, M. 1913. Zur chronologie der alten kulturen von Ica. Journal de la Société des Américanistes de Paris 10 :341-367.

Unkel, I., M. Reindel, H. Gorbahn, J. Isla Cuadrado, B. Kromer and V. Sossna 2012. A comprehensive numerical chronology for the pre-Columbian cultures of the Palpa valleys, south coast of Peru. Journal of Archaeological Science 39: 2294-2303.

Vaughn, K. J., J. W. Eerkens, M. Linares Grados and M.J. Edwards 2007. Hematite mining in the ancient Americas: Mina Primavera, a 2,000 year old Peruvian mine. JOM: The Journal of The Minerals, Metals \& Materials Society 59:21-25. 
